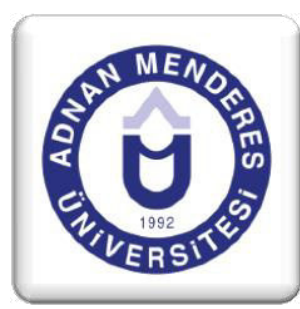

\title{
Denizli Kenti ve İlinde Yönetsel Ölçek Arayışları (1976-2014): Dört Bütünşehir (Belediyesi) Söylemi / Tasavvuru (2001-2014) ve Büyükşehir Belediyesi Statüsü (2012-2014)
}

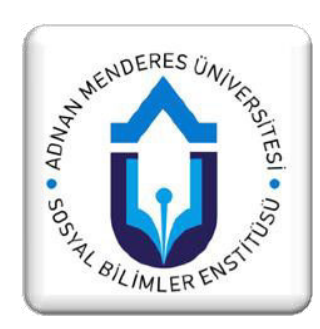

\section{Özet}

Hüseyin

Merkez ilçedeki 34 köy 1976 ylında Denizli Belediyesine mücavir alandaki köy ÖZGÜR* olarak bağlanmıştı. Mücavir alan uygulaması gevşek bir bütünleştirme süreci olup köylerin belediyeleşmesiyle tersine çevrilebilir. 1989-1999 döneminde Denizli Belediyesinin mücavirindeki köylerin çoğu belediyeleşmiştir. Genelde birkaç köy birleşerek Merkez ilçede 17 yeni belediye kurulmasıyla idari parçalanma olmuştu. 1993-2000 döneminde yoğunlaşan ve 2012 sonuna kadar devam eden büyükşehir belediyesi kurma çabalarında 2000 yılı sonunda umut iyice azalmıştı. 2001 yılında 14 belediyenin gönüllü katılımı ve kısa ömürlü bir üst meclis denemesine geçilmişti. Dönemin Belediye Başkanı Ali Aygören'in bu tasavvuru ve çabasıyla bütünşehir terimi Türkiye'de de ilk kez kullanıldı. 2001-2014 döneminde, Denizli'de dört, 5216 ve 5390 sayılı Kanunlarla özellikle 2004-2005 yıllarında Denizli dışında bir, toplamda beş farklı bütünşehir belediyesi tasavvuru ve söylemi bulunmaktadır. Bu çalışmada genelde Türkiye özelde ve özellikle Denizli için bütünşehir (belediyesi) söylemleri ve tasavvurları hikâye ve analiz edilmektedir. Denizli dışındaki bütünşehir ve benzeri söylemler ve düzenlemelerin ele alınışının amacı Denizli'deki bütünşehir tasavvurlarını daha iyi anlamak ve analizlerde bütünlük sağlamaktır.

*Prof. Dr.

Pamukkale

Üniversitesi

Anahtar kelimeler: Bütünşehir, (5026, 5216, 5393, 5747, 6360, sayılı) Kanunlar, büyükşehir belediyesi statüsü, kentsel alan yönetimi, yerel yönetim ölçeği, kent ölçeği, yerel kamu hizmeti, ilçe, Pamukkale, Denizli

Siyaset Bilimi ve Kamu Yönetimi Bölümü 


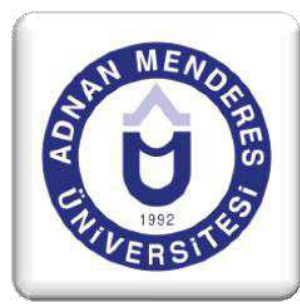

\section{Managerial Scale Quests In Denizli City and Province (1976-2014): Four Unicity (Muiicipality) Discourses and Conceives (2001-2014) and Greater / Metropolitan Municipality Status (2012-2014) Law No. 6360 and Effects}

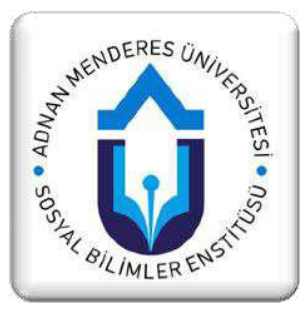

\section{Abstract}

The 34 villages in Central District were connected as a village in contiguous area in Denizli in 1976. Application of contiguous areas is a loose integration process and could be reversed with municipalization of villages. Most of villages in the contiguous area in the municipality of Denizli become municipality in the 19891999 period. With the establishment of 17 new municipalities in the Central District by combining some villages into a municipality had caused the administrative fragmentation. Efforts of establishing metropolitan municipality for Denizli were strengthened in the years of 1993-2000 and continued till the end of 2012; but hopes for this issue had decreased in the end of 2000. In 2001, it has been applied a short-lived upper council trial with the voluntary participation of 14 municipalities. The term unicity or united city (bütünşehir) was first used with efforts and conceives of Mayor Ali Aygören. In 2001-2014 term, four in Denizli, one out of Denizli, and totally five unicity municipality conceives and discourses have been observed in Turkey. In this paper, unicity discourses and conceives for Turkey in general and Denizli in particular is narrated and analyzed. The purpose of examining unicity and other similar discourses and regulations outside of Denizli is for the sake of better understanding unicity conceives in/for Denizli and ensuring integrity of the analysis.

Keywords: Unicity, United City, Bütünşehir, Laws (numbered 5026, 5216, 5393, 5747, 6360), greater / metropolitan municipality status, management of urban areas, local government scale, optimum urban scale, local government services, county / district, Pamukkale, Denizli.

Hüseyin

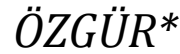

*Prof. Dr.

Pamukkale

Üniversitesi

Siyaset Bilimi ve Kamu Yönetimi Bölümü 


\section{GİRIŞ YERINE: DENIZLI'DE VE TÜRKIYY'DE BÜTÜNŞEHİR (BELEDIYYESİ) VE BÜTÜNŞEHIR BENZERİ YEREL/ ÖLÇEK TASAVVURLARI VE UYGULAMALARINA ÖZET BAKIŞ (1976-2014)*}

Büyükşehir belediyesi ve bütünşehir benzeri küçük belediye ve köylerin il veya ilçe merkezi uygulamalar bazı eserlerde toplu olarak irdelenmiştir (Eke, 1982; Güler, 1987: 119-141; Keleş, 2012a; 2012b; Özgür, 2008a; Özgür, Savaş Yavuzçehre ve Ciğeroğlu, 2007a; 2007b; Tuzcuoğlu, 2003). Denizli'de bütünşehir (belediyesi) terimine yönelik kapsamlı inceleme Özgür $(2007 ; 2008 b ; 2012)$ tarafından muhtelif zamanlarda yapılmıștır. Denizli bütünșehir belediyesine dair kapsamlı incelemeler Özgür (2008b; 2009; 2012) tarafından gerçekleştirilmiştir.

1980 yılında 34 Numaralı Karar ve 2561 Sayılı Kanun 34 numaralı Milli Güvenlik Konseyi Kararı 12 Eylül'den hemen üç ay sonra 11.12 .1980 gün ve 17187 sayılı RG'de yayımlanmıştır. (Güler, 1987). Nüfusu 300.000'i geçen il merkezi ana belediyelerin etrafındaki diğer mekanizma Milli Güvenlik Kurulunun 34 sayılı kararı ve onu netleştirip iyileştiren 1981 yılındaki 2561 sayılı Kanun (Güler, 1987) dışında metropolitenleşen ve/veya bütünleşen kentsel alanları yönetmek ve yerel yönetimlerde ölçek arayış1 ihtiyacına cevap vermek için 1984 yılına kadar çok az sayıda ve nispeten önemsiz düzenleme ve mekanizmalar ortaya konabilmiştir (Ciğeroğlu, 2007; Özgür, 2008a). Bunlar özellikle, -2000'li yıllara kadar sayıları, mali güçleri ve hizmet kapasiteleri oldukça sınırlı olan- kentsel nitelikli mahalli idare birlikleri, belediye şubeleri, imar planlama büroları ve mücavir alan düzenlemeleridir.

2004 yılı ortasına kadar yürürlükte kalan 1580 sayılı ve 1930 tarihli eski Belediye Kanunu ile 1956 yılında yürürlüğe giren ve 1985 yılında 3194 kanun numarasıyla yenisi yasalaşsa da mücavir alanla ilgili benzer düzenlemeleri içermeye devam eden İmar Kanunu köylerin veya köy kısımlarının bir belediye tarafından mücavir alana alınması, idari açıdan parçalanmış veya çevresine doğru gelişme gösteren merkezde yoğun ancak çevrede köy ve köyaltı (köy bağlısı) yerleşimlerin varlı̆̆ halinde seyrek dokulu kentsel alanları yönetmek için getirdiği nadir mekanizmalardan birisidir (Yılmaz ve Bozkurt, 2007).

İlk kullanıldığı 2001 yılından itibaren birkaç kez anlam ve coğrafi kapsamı değişen (genişleyen) ve hukuki mevzuatta hiçbir zaman karşıllığı olmayan bütünşehir belediyesi kavramının doğuşu, gelişimi ve farklı anlamları/tasarımları (tasavvurları) özellikle Denizli ili ve kenti bağlamında ele alınmaktadır. Ocak 2001'den Haziran 2014'e geçen 13 yılda Denizli dört farklı bütünşehir belediyesi tasavvuruna konu olmuştur. Türkiye'de ilk bütünşehir ifadesi 2001 yılı Ocak ayında dönemin Denizli Belediye Başkanı Ali Aygören kullandı. Denizli'de ikinci bütünşehir tasavvuru Aralık 2003'te veto edilen Denizli'ye özgü 5026 numaralı kanundu. Öte yandan, Temmuz 2004'de yürürlüğe giren 5216 sayılı yeni Büyükşehir Belediyesi Kanunuyla o dönemdeki 16 büyükşehir belediyesinin hepsinin sahaları değişik ölçülerde genişlemişti. $\mathrm{Bu}$ genişlemeye her BşB'nde bütünşehir denmese de, İzmir gibi bazılarında bütünşehir terimi kullanıldı. $\mathrm{Bu}$ bütünşehir söylem ve tasavvuru Denizli’yi kapsamadı çünkü Denizli ancak Mart 2014 yerel seçimlerinde büyükşehir belediyesi olabildi. Büyükşehir belediyelerinin 2004'de 5216 sayılı Kanunla genişleyen alanın en ucundaki ilçe belediyeleriyle ilgili olarak da bütünşehir terimi en çok İzmir'de Aliağa ve Selçuk Belediyeleri için dillendirildi. 2004'den önce Denizli'de iki farklı bütünşehir tasavvuru ortaya çıkmıştı bile. Denizli' deki iki farklı bütünşehir söylemlerinin Ege Bölgesi bölgesel medyasında yer almasının da olası etkileriyle terim yeni bir içerikle Denizli’den sonra ilk olarak İzmir'e (özellikle Selçuk, Aliağa ve İzmir Büyükşehir Belediyesine) sonra da Türkiye’ye yayılmış gözükmektedir.

2004 y1lındaki 5216 sayılı yeni Kanunun sınır hükümlerinin tüm (16) büyükşehir belediyelerinde uygulanması özellikle İzmir ve Diyarbakır örneklerinde bütünşehir terimiyle de dillendirilen bir alan genişlemesi tasarımı ortaya çıkardı. Bu düzenleme ve söylem (tasavvur / tasarım) doğal olarak o dönemde büyükşehir belediyesi statüsünün dışında olan Denizli için kullanılmadı.

\footnotetext{
* Bu çalışma Süleyman Demirel Üniversitesi Kamu Yönetimi Bölümü öğretim üyesi Doç.Dr. Murat Okcu yürütücülüğünde Nisan 2013'te başlayan 24 ay süreli TÜBİTAK 1001 SOBAG 112K538 nolu araştırma projesinin bir ürünüdür ve Proje tarafindan desteklenmektedir.
} 
Türkiye için genel bir düzenleme olan 5393 sayılı Belediye Kanununun 11. Maddesi 1. Fıkrasındaki katma ve birleştirme düzenlemesinin Denizli'de kullanımı Denizli'de üçüncü tip bütünşehir tasavvuru ve söylemidir. Düzenlemenin Denizli dışındaki bazı uygulamalarında da bütünşehir terimi kullanılmıştır. 2012 yılındaki 6360 ve onun 2013 yılında Ordu İli için tamamlayıcısı 6447 sayılı Kanunlardaki il mülki sınırlarında büyükşehir belediyesi ise son, güncel ve Nisan 2014 itibariyle Türkiye nüfusunun yüzde 70'den fazlasını kapsayan 30 büyükşehir belediyesinde ortak bütünşehir söylemi ve tasavvurudur.

Çalışmanın ilk bölümünde bütünşehir tasavvurlarına giden yolda Denizli kentindeki idari ve siyasi parçalanmışlık ile mücavir alan düzenlemesi ele alınmaktadır. 2001 yılında komşu 14 belediyenin ortak çalışması anlamındaki bütünşehir teriminin Denizli'de ve Türkiye'de ortaya çıkışı ve ilk (1.) anlamı/türü ikinci bölümde irdelenmektedir. Üçüncü bölümde Aralık 2003'de T.B.M.M'den geçip veto edilen Denizli'ye özel ve 47 yerleşimi ilgilendiren 5026 sayılı Kanunun yarattığı ikinci bütünşehir söylemi ve tasavvuru detaylı olarak hikâye edilmektedir. Dördüncü bölümde 5393 sayılı Belediye Kanununun "tüzel kişiliğin sona erdirilmesi” ne ilişkin 11/1. maddesindeki düzenlemeyle ortaya çıkan 5026'ya göre 23 yerleşimi kapsayan bütünşehir tasavvuru detaylıca tanıtılıp analiz edilmektedir. 13 ilde yeni büyükşehir belediyesi kurulması ve mevcut 14'te de sinırları il mülki sınırlarına Kasım 2012'deki 6360 sayılı özel/torba Kanunun etkisindeki dördüncü tür bütünşehir tasavvuru daha çok Denizli özeliyle beşinci bölümde ele alınmaktadır.

Denizli'deki bütünşehir terimlerinin daha iyi anlaşılabilmesi ve 6360 sayılı Kanunun getirdiği yeni bütünşehir belediyesi tasavvurunun da eklenerek hikâyenin daha bütünlükle kaleme alınması bu makalenin amaç ve katkılarından birisidir. Aynı zamanda, bu makalede, Denizli'de de bir dönem yaygın olarak kullanılan ve bütünşehir tasavvurlarına benzeyen özellikler taşıyan kapsamlı mücavir alan düzenlemesinden de kısaca bahsedilmekle hikayenin geçmişi 1976 yılına kadar getirilmekte, tablolar yoluyla hem bütünşehir söylemleri Türkiye ve Denizli'de karşılaştırılmakta hem de Denizli'de uygulaması olmayan bütünşehir benzeri (1981 yılındaki 2561 sayılı Kanun ile) bütünşehir teriminin kullanıldığ1 5216 ve 5390 sayılı Kanunları bütünlük açısından bu çalışmaya, özellikle tablolarda, tarihsel sırada dahil edilmektedir.

\section{BÜTÜNŞEHİR TERIMSIZ KENTSEL ALAN YÖNETIMI MODELİ VE UYGULAMASI OLARAK DENIZLI'DE KAPSAMLI MÜCAVIR ALAN (1976-1989)}

Özellikle Denizli özelinde kapsamlı mücavir alanı uygulamasını yönetim, mekânsal planlama, siyaset açılarından bir bütünşehir tasavvuru olarak düşünmek mümkündür; ancak diğer bütünşehir tasavvurlarından temel iki farkı sözcüğün Türkiye'de ve dolayısıyla Denizli'de hiç kullanılmamış olması ve mücavir alandaki köylerle ilgili belediye arasında köylerin gerekli şartları taşıması halinde belediyeleşerek kalıcılığı garanti olmayan gevşek bir bağın varlığıdır. Aslında mücavir alan düzenlemesi de köy statüsündeki yerleşimlerin ana belediyeye bağlanması suretiyle Denizli'de ortaya çıkan dört farklı bütünşehir tasavvur ve tasarımının büyükşehir belediyesi hariç- ilk üçüne benzer sonuçlar doğuran bir düzenleme olup Denizli'de oldukça yaygın olarak, özellikle 1976-1989 döneminde uygulandı.

1970 sonlarında, "bütünşehir (belediyesi)" sözcüğü telaffuz edilmeksizin, Başkan Hasan Gönüllü döneminde Merkez İlçedeki 34 köy Denizli Belediyesinin mücavir alanına alınarak bu köylerdeki imar ve yapılaşma durumunun kontrol edilmesi ile şehrin gelişmesine daha kolay yön verilmesi amaçlanmaktaydı. Ancak mücavir alandaki köylerin çoğu 1980 sonlarında ve 1990'lı yıllarda belediyeleşti. Bu süreçte Denizli Belediyesinden hoşnutsuzluk, Türkiye çapında belediyeleşme furyası, mücavir alanda yeterli hizmet alamama şikâyetleri, mücavirdeki köylerin belediye olmaları yönünde bazı yerel siyasetçinin telkinleri, bazı kişilerin belediye meclis üyesi/başkanı olma arzuları gibi nedenler rol oynamıştı.

Denizli Merkez İlçede, Denizli'nin diğer ilçeleri ve Türkiye'de mücavir alandaki köyler başta olmak üzere köy ve köy bağl1s1 yerleşim ünitelerinin 1989-2002 döneminde belediyeleşmesinin tersine süreç ve düzenlemeleri bütünşehir (belediyesi) söylemleri ve tasavvurlarında sıklıkla bulmak mümkündür. 1996-2001 dönemindeki yerel yönetimler yasa tasarılarında ve 2004 Belediye Kanununda ana belediyelerin komşu belediye ve -mücavir alandakiler dahil-- köyleri kendisine mahalle olarak katmalarını kolaylaştıran bütünşehir ve bütünleştirme düzenlemeleri (Torlak ve Sezer, 2005) ihtiyaç olmuştur. Bu düzenleme 5393 say1lı Kanunun 11/1. Maddesiyle de ilgilidir. 
Tablo 1: Denizli’de Bütünşehir Öncesi (1976-2001) Kentsel Alan Yönetimi Durumu

\begin{tabular}{|l|l|l|}
\hline Bütünşehir (Belediyesi) Tanımı ve Temel Özellikleri (Kısaca) & $\begin{array}{l}\text { Denizli’de bütünşehir } \\
\text { benzeri tasarımın adı }\end{array}$ & $\begin{array}{l}\text { Dönemi: Ay ve } \\
\text { yıl olarak }\end{array}$ \\
\hline $\begin{array}{l}\text { Bütünşehir öncesi -1: İdari parçalanma öncesi, mücavir alan. Denizli } \\
\begin{array}{l}\text { Merkez ilçede bütünşehir benzeri etkiler gösteren ancak bütünşehir } \\
\text { sözcüğ̈ kullanılmadan mücavir alan ve belediye birlikleri denemesi. }\end{array}\end{array}$ & $\begin{array}{l}\text { Bütünşehir benzeri: } \\
\text { Köyleri mücavire alma }\end{array}$ & $\begin{array}{l}06.1976- \\
03.1989\end{array}$ \\
\hline $\begin{array}{l}\text { Bütünşehir öncesi -2: İdari ve siyasi parçalanma. Türkiye geneline } \\
\text { paralel olarak Merkez ilçede ve diğer ilçelerde yeni belediyeler. }\end{array}$ & $\begin{array}{l}\text { Belediyeleşme ve } \\
\text { parçalanma }\end{array}$ & $\begin{array}{l}04.1989- \\
12.2000\end{array}$ \\
\hline
\end{tabular}

\section{DENİZLİ MERKEZ İLÇEDE İDARİ PARÇALANMA (BELEDİYELEŞME) (1989-2001/2006) VE KENTSEL ALANDA BELEDIYYE SAYISININ AZALTILMASI (2006/2009-2012/2014) SÜREÇLERİ}

Bir yandan idari parçalanma artarken diğer yandan “yıldızı parlayan kent” Denizli'ye büyükşehir belediyesi statüsü için, özellikle 1993-2000 yıllarında olmak üzere, 1990'dan günümüze, farklı partilerden milletvekilleri değişik veya aynen tekrarlayan tasarımlarla kanun teklifleri sunmuşlardır. Denizli Belediyesi, siyasi partiler, STK'lar ve odalar da onlara değişen ölçülerde destek vermişlerdir (Denizli'nin büyükşehir belediyesi deneyimleri için bakınız: Ciğeroğlu, 2007; Özgür, 2007; 2008b; 2009; 2012; Özgür, Kösecik ve Ciğeroğlu, 2007a; 2007b; Özgür ve Kösecik, 2006; Savaş ve Yavuzçehre, 2011).

1970 ortalarından itibaren Denizli'de kentsel alanın etkili ve verimli şekilde yönetilmesinin önündeki önemli engellerden birisi parçalanmış idari yapıydı. Denizli Belediyesinin etrafındaki irili ufaklı belediye ve köyler kentin sağlıklı büyümesi ve gelişmesini kararı 2006 yılında alınan uygulaması 2009 yerel seçimlerinde gerçekleşen 5393 sayılı yeni Belediye Kanununun 11. Maddesi 1. fikrasına kadar zorlaştırmaktayd1. 1930 yılında yasalaşan eski 1580 sayılı Belediye Kanununa göre, nüfusu 2000'i geçen yerlerde belediye kurulabilmesinin de etkisiyle Merkez İlçede belediye sayısı 1999-2009 döneminde tavan yaparak 22'ye yükselmişti (Tablo 1). Denizli Merkez İlçedeki 22 belediyenin 21'i 1961-1999 döneminde kuruldu. 2012 yılı sonunda 6360 sayılı Kanunla Pamukkale ve Merkezefendi olarak iki ilçeye bölünen 2008 y1lındaki Merkez İlçe sınırlarında, 1960-1969 döneminde üç, 1970-1979 döneminde iki, 1980-1989 döneminde iki, 1990-1999 döneminde 14 adet belediye kuruldu. Bir başka açıdan, Denizli Merkez İlçede 1876 ile 1960 arasında sadece Denizli Belediyesi varken 1961'de sayı ikiye, 1971'de altiya, 1987'de yediye, 1992'de dokuza ulaştı. 1994-1999 arasında hızlı belediyeleşme nedeniyle 1992'de bile 9 olan belediye sayısı 1999'da 22 oldu. Böylece Denizli kentsel alanı (bakınız: Ciğeroğlu, 2007) ve Merkez İlçesi 1990'larda hızlı idari/siyasi parçalanma yaşadı (Tablo 1).

\section{Tablo 2: 1976-2014 Döneminde Denizli Merkez ve Akköy İlçelerinde Bulunan veya Kapanan} Belediyelerin ve İlçelerin Kuruluş Yılları

\begin{tabular}{|c|c|c|c|c|c|}
\hline Belediye & Kuruluş & Belediye & Kuruluş & Belediye / İlçe / & Kuruluş \\
\hline Ad1 & Y1l1 & Ad 1 & Y1l1 & Büyükşehir Adı & Y1l1 \\
\hline Denizli (M) & 1876 & Bağbaşı(M) & 1994 & Gökpınar (M) & 1999 \\
\hline Başkarcı (M) & 1961 & Kayhan (M) & 1994 & Servergazi (M) & 1999 \\
\hline Uzunpınar (M) & 1967 & Kinıklı (M) & 1994 & Gölemezli (A) & 1994 \\
\hline Aşağışamlı (M) & 1969 & Korucuk (M) & 1994 & & \\
\hline Gözler (M) & 1971 & Pinarkent (M) & 1994 & Akköy İlçesi (A) & 1999 \\
\hline Irliganlı (M) & 1971 & Bereketli (M) & 1995 & Merkezefendi İlçesi (M/2) & 2012 \\
\hline Gümüşler (M) & 1987 & Cankurtaran $(\mathrm{M})$ & 1995 & Pamukkale İlçesi $(\mathrm{M}+\mathrm{A} / \approx 2)$ & 2012 \\
\hline Pamukkale (M) & 1989 & Hallaçlar(M) & 1996 & Merkezefendi İlçe Belediyesi & 2012 \\
\hline Karahayıt(M) & 1992 & Göveçlik (M) & 1998 & Pamukkale İlçe Belediyesi & 2012 \\
\hline Akkale (M) & 1994 & Üçler (M) & 1998 & Denizli Büyükşehir Belediyesi & 2012 \\
\hline
\end{tabular}

Not: $\mathrm{M}=$ Merkez İlçe, $\mathrm{A}=$ Akköy İlçesi, $\mathrm{M}+\mathrm{A} / \approx 2=$ Merkez ve Akköy İlçelerine taşan ama yeni ilçeler. Pamukkale İlçesi eski Akköy’ün neredeyse tamamını kapsamaktadır. 
Kaynaklar: Denizli Belediyesi; Ciğeroğlu, 2007; Yerelnet, www.yerelnet.org.tr; İller İdaresi Genel Müdürlüğü, www.illeridaresi.gov.tr.

1976 Denizli depreminden sonra hem kat artışıyla dikey hem de çevreye doğru yayılan nüfus artışıyla bu belediye ve köylerden merkeze daha yakın olanlar içiçe geçmiş veya arada küçük boşluklar olsa da birbiriyle kuvvetli etkileşimli bir kentsel alan bütünü oluşturmuşlardır. Bu parçalanmış idari yapının sıkıntılarını gidermek için Denizli'de büyükşehir belediyesi statüsüne dair kanun teklifleri 1993'ten itibaren TBMM'ye sunulurken tekliflerin ivedilikle gündeme alınmasına çabalandı (bakınız: Özgür, 2008b; 2009; 2012). Yerelde de, 1999-2004 dönemi Denizli Belediye Başkanı Ali Aygören (2001: 5-6) Büyükşehir Deneyimleri Işı̆̆ında Denizli Panel ve Forumunda şunları söyledi:

Biz 1990'da başlatılan, 'Denizli büyükşehir olsun' konusunu her ortamda gündeme getirdik. Neye getirdik? Önce, Denizli’ deki imar planlarının bu kadar güzel yapılmasına rağmen sahip çıkılamayışından, ufacık köylerin imar planlarının yapıldıktan sonra sınılarımıza dahil edilmeyip, o köylerin belediye olmasına müsaade etmemizden sorunlar çıktı. Eğer o köyler belediye olmasaydı da mahalle olsaydı, bu planlarımıza biz sahip çıkabilseydik, bugün belki de Denizli’nin büyükşehir olması çok önemli değildi. ... Merkeze sıkışmış bir Denizli, merkezden dışarıya adım atmamız mümkün olmayan bir Denizli, herhangi bir sanayi gelişimini ve imar planını yapamayacak hale gelmiş bir Denizli ve arkasından da bunun çözümleri için büyükşehir hedefini arzu eden bir Denizli.

1993 yılında 7 il merkezinde büyükşehir belediyesi kurulmasından 2012 y1lındaki 6360 sayılı Kanuna kadar bu statüye ilişkin mücadele Denizli'de kesintisiz olarak devam etti. 1998-2002 dönemindeki büyükşsehir belediyesi kurulma şartlarını da düzenleyen yerel yönetimler kanun tasarılarındaki 300.000 veya 500.000 nüfus ölçütleri bazen Denizli'yi hayli umutlandırsa da, Denizli ancak 6360 sayılı Kanunla bu statüye kavuşabildi. 2000'lerin başında büyükşehir belediyesi statüsü umudunun azaldığını düşünen Başkan Ali Aygören Ocak 2001'de bir alternatif ve geçiş düzenlemesi olarak "bütünşehir (belediyesi)" terimini kazandırdı. Aygören'in bütünşehir tasarımına giden yolda 1976'da Denizli'de mücavire alınan 34 köyün büyük kısmı 1987-1999 döneminde belediyeleşerek kentsel alan ve dolayısıyla Merkez İlçe idari ve siyasi açılardan parçalandı. Yeni kurulan belde belediyelerinden bazıları küçük nüfuslarına rağmen alan büyüklükleri itibariyle Denizli Belediyesi ile yarışmaktaydı.

1580 sayılı eski Belediye Kanunu döneminde (1930-2004) belediye kurulmasının kolaylığ ve belediyeleşme isteğinin özellikle 1980 'ler ve 1990'larda yükselişi gibi nedenlerle, birçok kentsel alanda idari/siyasi parçalanmışlık düzeyi artmıştı.

Tablo 3: Denizli İlinde 1976-2014 Döneminde İlçeler: Kuruluş, İsim ve Sınır Dönüşümleri

\begin{tabular}{|l|l|l|l|l|l|l|}
\hline & İlçe Adı & $\begin{array}{l}\text { Kanun } \\
\text { No }\end{array}$ & $\begin{array}{l}\text { Kuruluş } \\
\text { Y1lı }\end{array}$ & $\begin{array}{l}\text { Dönüşüm / } \\
\text { Kapanış Y1lı } \\
\text { ve Kanunu }\end{array}$ & $\begin{array}{l}\text { Kurulduğu } \\
\text { İlçe/ler }\end{array}$ & Kapsam ve açılama \\
\hline 1 & Merkez & -- & $\begin{array}{l}19 . \\
\text { Yüzyıl }\end{array}$ & $\begin{array}{l}2012 \\
(6360)\end{array}$ & $\begin{array}{l}\text { Aydın } \\
\text { Vilayeti }\end{array}$ & $\begin{array}{l}\text { Merkez ve Akköy ilçeleri toplamında iki } \\
\text { ilçe kuruldu: Merkezefendi, Akköy } \\
\text { dönüştürülüp genişletilerek Pamukkale }\end{array}$ \\
\hline 2 & Akköy & 3644 & 1990 & $\begin{array}{l}2012 \\
(6360)\end{array}$ & Merkez & $\begin{array}{l}\text { Akköy İlçesi Pamukkale'ye dönüştürüldü, } \\
\text { Pamukkale İlçesi Merkez ilçeden de } \\
\text { belediye, köy ve mahalleler aldı. }\end{array}$ \\
\hline 3 & Merkezefendi & 6360 & 2012 & & Merkez & $\begin{array}{l}\text { Merkez İlçenin geri kalanı Pamukkale } \\
\text { (genişletilmiş eski Akköy) ilçesine geçti }\end{array}$ \\
\hline 4 & Pamukkale & 3644 & 1990 & 2012 & $\begin{array}{l}\text { Merkez, } \\
\text { Akköy }\end{array}$ & $\begin{array}{l}\text { İlçedeki eski Pamukkale belde belediyesi } \\
\text { Nisan 2014'de Pamukkale Mahallesi oldu. }\end{array}$ \\
\hline 5 & Babadağ & 3392 & 1987 & -- & Sarayköy & $\begin{array}{l}\text { Denizli'nin nüfus ve yüzölçümü olarak en } \\
\text { küçük ilçelerinden birisidir. }\end{array}$ \\
\hline 6 & Baklan & 3644 & 1990 & -- & Çal & $\begin{array}{l}\text { 1867'de kaza olmuş, 1885'de kaza teşkilat1 } \\
\text { kaldırılarak nahiye haline getirilmiştir. }\end{array}$ \\
\hline 7 & Bekilli & 3392 & 1987 & -- & $\begin{array}{l}\text { Çal } \\
\text { 1884'de İzmir İli'ne; sonra Denizli’ye } \\
\text { bağliydı. 1910 yılında Çal ilçesi bucağ1dır. }\end{array}$ \\
\hline
\end{tabular}




\begin{tabular}{|l|l|l|l|l|l|l|}
\hline 8 & Beyağaç & 3644 & 1990 & -- & Kale & $\begin{array}{l}\text { Denizli’nin nüfus ve yüzölçümü olarak en } \\
\text { küçük ilçelerinden birisidir. }\end{array}$ \\
\hline 9 & Bozkurt & 3644 & 1990 & -- & Çardak & $\begin{array}{l}1876-1955 \text { arası köy statüsünde, 1955 } \\
\text { y1lında Bucak, 1956 y1lında belediye. }\end{array}$ \\
\hline 10 & Honaz & 3392 & 1987 & -- & Merkez & $\begin{array}{l}\text { Merkez ilçenin bucağıydı. Kakllk yerleşimi } \\
\text { ve civarı ilçe kurulması teklifine konu oldu. }\end{array}$ \\
\hline 11 & Serinhisar & 3392 & 1987 & -- & Acıpayam & $\begin{array}{l}\text { Tavas, Acıpayam, Pamukkale ve Honaz } \\
\text { ilçelerine komşudur. }\end{array}$ \\
\hline
\end{tabular}

Kaynaklar: İller İdaresi Genel Müdürlüğü verileri, Bekilli, Honaz, Serinhisar ilçelerinin kuruluşuna dair 103 ilçe kurulması hakkında 3392 sayılı Kanun, 19.06.1987 tarihli TBMM Tutanak Dergisi, ilçelerin internet sayfaları.

Denizli ilinde yeni ilçeler kurulması -Akköy İlçesinden dönüştürülen Pamukkale dışında- ilçelerin Mart 2014 seçimlerinde büyükşehir belediyesi haline gelmesiyle idari parçalanmayı ve ilçeler, dolayısıyla belediyeler arası hem alansal hem de özellikle nüfus olarak büyüklük farklarını artırmıştır. Yeni kurulan ilçelerden sadece Honaz 32.324'lük nüfusuyla önemli büyüklüğe erişmiştir. Elbette bu ilçelerin sınırlarında kurulan belde belediyeleri de idari parçalanmayı Nisan 2014'e kadar arttırmışt1. 5393/11. Maddeden istifadeyle bir belediye ve iki köyün 2008 yılında alınan ve Mart 2009'da uygulanan kararla Çivril İlçesinde idari parçalanma daha erken azaltılmıştı.

Beyhan Aslan Denizli'de büyükşehir belediyesi kurulması teklifinde (1999) özetle Denizli’nin hizmet alanının genişlemekte olduğuna ve kentin enerji, içme suyu, kanalizasyon, toplu taşıma, imar planı uygulamalarının birbirleriyle uyumlu olmadığını belirtmekteydi. Büyükşehir Deneyimleri Işığında Denizli Panel ve Forumunda (2001) dönemin Mimarlar Odası Denizli Şubesi II. Başkanı Turgay Üçyıldız Denizli'deki parçalanmayı şöyle anlatmaktaydı:

Merkez belediyemiz, 21 belde tarafindan kıskaç arasına alınmış bir haldedir ve çok küçük bir alana sıkışmış vaziyettedir. 21 belde belediyesinin olmasının asıl sebepleri; bugüne kadar gelen belediye başkanları ve il genel meclisi üyeleridir. ... 1964 planımız, 1980 yllında 60.000 nüfusa hitap edecek şekilde hazırlanmıştır, ama 1980'den sonra Denizli'de sanayiden dolayı nüfus patlaması olmuştur. Tabii gelen kişiler konut edinebilmek için çevreye yayılmaya başlamışlardır. Belediye başkanlarımız sağ olsun; onlara iskân açabilmek için Merkez köylerin arazilerini kullanmışlardır. Bu arazileri kullanırken de, Merkez Belediye köylere yapacağı görevleri yapmamıştr. Bu olayı da siyasiler kullanmış, köyleri hareketlendirmiş ve demiş ki; 'sizin kullanacağınız bütün yerleri Merkez Belediye alıyor, siz 2.000 nüfusu geçmişsiniz, neden belediye olmuyorsunuz? Belediye olun, bu arazileri siz kulanın. Hiç olmazsa devletin mali katkıları olur' diye siyasiler bunları harekete geçiriyor ve Merkez köylerimiz referandumla belde belediyeleri haline geliyor.

Denizli Merkez İlçede ve onu komşulayan ilçelerde büyükşehir belediyesi kurulması ihtimali 2000 yılında zayıfladı. Belediye Başkanı Ali Aygören, Ocak 2001'de Denizli Merkez İlçedeki birbiriyle içiçe geçmiş 14 belediyeyi ortak karar üretme amacıyla meclis ve çalışma platformu oluşturmaya çabaladı. Bu çabaya yönelik kimi şüpheler ve çekincelere rağmen 14 belediyenin başkanı ve Denizli Belediyesi birkaç kez katılım da göstererek ortak toplantı yapmak suretiyle birinci (ilk) bütünşehir tasavvuruna destek verdiler.

14 belediyeyi biraraya getirerek yerel hizmetler için ortak hareket etmeyi amaçlayan bu bütünşehir fikri içerik ve kapsam değiştirerek, 1 ilçe merkezi, 22 belediye ve 25 köyü (47 yerleşimi) Denizli Belediyesine mahalle olarak bağlamayı amaçlayan ve AK Partili Denizli Milletvekilleri tarafindan Meclise sunuldu. Merkez İlçe'nin Gözler ve Uzunpınar Belediyeleri ile bazı köyleri Teklifin dışındaydı. Aksine, başka/komşu ilçelerin Duacılı (Sarayköy İlçesi), Gölemezli (Akköy İlçesi) ve Kocabaş (Honaz İlçesi) Belediyeleri Teklifin içindeydi. Bu Teklif Meclis İçişleri Komisyonunun da değişiklik önergeleriyle, 47 yerleşimi içerecek ve Akköy İlçe Merkezini dışarıda bırakacak şekilde TBMM'den geçerek 5026 Kanun numarasını aldı. Mart 2004 yerel seçimlerinde 47 yerleşimi mahalleye dönüştürmeyi öngören Kanunu 30.12.2003'te 10. Cumhurbaşkanı A.N. Sezer seçime 1 yıldan az süre kalması tali nedeniyle veto etti. Bu Denizli’ye özel düzenleme ikinci bütünşehir belediyesi tasavvurudur. Denizli'de ve ulusal basında "Denizli Bütünşehir (Belediyesi) Yasası" diye anılan ve tam adı "Bazı Belediye ve Köylerin Denizli Belediyesine Katılmasına 
İlişkin Kanun olan bu düzenlemenin metninde bütünşehir terimi geçmez. Denizli halkı, idari ve siyasi yöneticiler, diğer ilgililer, medya bu Teklifin kapsamına da bütünşehir demişti.

Yerel hizmetlerin sunumu açısından çok sayıda belediye ve köyün varlığından mustarip olduğu iddia edilen Denizli kentsel alanının yönetimi için 22 belediye ve 25 köyü Denizli Belediyesine katmayı öngören Teklif 5026 kanun numarasıyla Aralık 2003'te Meclis'ten geçse de; ancak aynı ay sonunda 10. Cumhurbaşkanı tarafından veto edildi. "Bütünşehir yasası" diye anılan 5026 sayılı Kanun (Teklifi), 10. Cumhurbaşkanı'nın vetosu dolayısıyla Denizli'de doğrudan uygulama şansı bulamadı. Madde gerekçesinde yer verilen Denizli ve Antakya'nın idari parçalanmışlı̆̆ söylemi ile 5393 sayılı Kanunun 11. maddesi düzenlemelerine veto edilen 5026 sayılı Denizli’ye özel Yasadaki düzenleme ve söylem öncülük etmiş olabilir.

Denizli'deki 5026 sayılı Kanun Teklifiyle gündeme gelen ikinci bütünşehir tasavvuruna ve 5393 sayılı Kanunun 11. Maddesi 1. Fikrasındaki üçüncü tasavvura akademik literatürde (örneğin, Ciğeroğlu, 2007; Çınar vd., 2013; Özgür, 2007; Özgür, Kösecik ve Ciğeroğlu, 2007a; 2007b; Özgür, Savaş Yavuzçehre ve Ciğeroğlu, 2007a; 2007b; Savaş Yavuzçehre, 2011) kısmen yer verildi.

Mart 2004'de Meclisten geçip veto edilen 5215 sayılı Belediye Kanunu kimi değişikliklerle önce 5272, sonra 5393 sayı numarasıyla kanunlaştı. 5393 sayılı Belediye Kanununun 11. Maddesinin gerekçesine göre "Denizli ve Hatay illerimizde olduğu gibi birçok belediye cadde ve sokaklarla birbirinden ayrılmış, görev ve yetkilerin kullanımı ile hizmetlerin sunumunda karmaşa yaşanmış, vatandaşlar ... hangi belediyeye başvuracaklarını şaşırmış, imar denetimleri ve kaçak yapılaşma ile mücadele yeterince yapılamamış(...)tır”. 5215, 5272 ve 5393'ün 11/1. maddesindeki "tüzel kişiliğin sona erdirilmesi” düzenlemesine göre, tüm il ve ilçe merkezi belediyelere, genel imar düzeni veya temel altyapı hizmetlerinin gerekli kılması durumunda, sınırlarına $5 \mathrm{~km}$ mesafedeki belediye ve köyleri kendilerine katabilir. Bu katılma işlemi tüzel kişiliği sona erdirilecek yerleşim birimlerinin hemşehrileri veya seçilmişlerinin rızasını gerektirmez. Belediye Kanununun 11/1. maddesi ana belediyelerin ilçe merkezi statüsü bulunmayan komşu belde belediyeleri ve köyleri Valilik talebi/görüşü, Danıştay görüşü ve müşterek kararnameyle tek taraflı iradeyle kendilerine katmalarının yolunu açtı. Denizli'de 13 belediye ve 10 köyde bu maddenin uygulanmasını kararlaştıran 2006/8352 sayılı sınır tespiti kararı (Üçlü Kararname) da Denizli'deki halk, basın ve diğer ilgililer tarafından yine "bütünşehir" belediyesi olarak isimlendirildi. Böylece --bu kez 2006-2014 döneminde (ağırlıkla 2009-2014 seçimleri arası dönemde) uygulamaya da yansıyan-- üçüncü bütünşehir tasarımı ortaya çıtı.

Belediye Kanununun 8. maddesi belediye-belediye, belediye-köy ve belediye-belediye-köylerde rıaya dayalı birleşmenin yolunu açtı ve yerleşim birimlerinin meskûn sahaları arasında 500 metre azami mesafeyi 5.000 metreye çıkard1. 5393 sayılı Kanunun 11. maddesi 2. fikrasıyla ve 2008 y1lındaki 5747 sayılı Kanunla en küçük belediyelerin köy statüsüne dönmesi düzenlendi. Bu düzenleme artık Mart 2014 yerel seçimleriyle, büyükşehir belediyelerini il sınırlarına genişleten, mevcut büyükşehir belediyesi sayısını 30'a yükselten ve büyükşehir sınırında belde belediyeleri ile köyleri mahalleye çeviren 6360 sayılı Kanunun dışında kalan illerde kullanılabilecektir. 
Tablo 4: Denizli’de ve Türkiye’de Bütünşehir (Belediyesi) Tasavvurları: Dönemleri, Ortaya Çıkışları ve Kısa İçerikleri

\begin{tabular}{|c|c|c|c|c|}
\hline $\begin{array}{l}\text { Bütünşehir } \\
\text { Tanımı (Kısaca) }\end{array}$ & $\begin{array}{l}\text { Dönemi, Öncüleri, Aktörleri ve Varsa } \\
\text { Temel Düzenlemeler }\end{array}$ & $\begin{array}{l}\text { Denizli'de ve Türkiye'de } \\
\text { bütünşehir terimi }\end{array}$ & $\begin{array}{l}\text { Bütünşehir Tasavvurunun Ortaya Çıkışı, } \\
\text { Tipi ve Anlamı }\end{array}$ & $\begin{array}{l}\text { Bütünşsehir Tasavvurunun Kapsadığı } \\
\text { Kentsel Alan ve Açıklamalar }\end{array}$ \\
\hline $\begin{array}{l}\text { Mücavir alan } \\
\text { düzenlemesi } \\
\text { gevşek idari } \\
\text { bağıyla sınır } \\
\text { genișlemesi }\end{array}$ & $\begin{array}{l}\text { 1976-1989 (kapsamlı mücavir alandan } \\
\text { belediyeleşmenin başlangıcına kadar) } \\
\text { 1976-1980: (12 Eylül } 1980 \text { Darbesine } \\
\text { kadar). CHP'li Hasan Gönüllü 1973- } \\
\text { 1980 dönemi belediye başkanı }\end{array}$ & $\begin{array}{l}\text { Denizli'de ve Türkiye'de } \\
\text { kesinlikle bütünşehir } \\
\text { terimi yok. Bütünşehir } \\
\text { benzeri mücavir alan } \\
\text { Denizli'de kapsamlı. }\end{array}$ & \multicolumn{2}{|c|}{$\begin{array}{l}\text { Ortaya çııışı İmar Kanununda yapılan değişiklikle belediyelerin aynı ilçe sınırında } \\
\text { mesafe sınırı olmadan istediği ve gerekçelendirdiği komşu köyleri imar ve altyapı } \\
\text { hizmetleri açısından kendi kontrolüne alması. Türkiye'deki en kapsamlı mücavir alan } \\
\text { uygulamalarından birisi Denizli’de } 1976 \text { yılında onanan kararla } 34 \text { köyün Belediye } \\
\text { mücavirine alınması idi. }\end{array}$} \\
\hline $\begin{array}{l}\text { Kanunla } \\
\text { kentte } \\
\text { oelde ve } \\
\text { lağv1 }\end{array}$ & $\begin{array}{l}\text { 1980: Milli Güvenlik Konseyi } 34 \text { sayılı } \\
\text { kararı } \\
\text { 1981: } 2561 \text { sayılı Kanun ( } 34 \text { sayılı } \\
\text { kararı güncelliyor ama ilave yerleşimde } \\
\text { düzenleme etkisi göstermiyor }\end{array}$ & $\begin{array}{l}\text { ir tasavvurları } \\
\text { ncak bütünşehir } \\
\text { lanılmiyor. } \\
\text { erleşimler tek } \\
\text { rla bağlaniyor. }\end{array}$ & \multicolumn{2}{|c|}{$\begin{array}{l}\text { Nüfusu 300.00’i geçen sekiz şehirde çevresindeki küçük belediye ve köyleri il } \\
\text { merkezi ana belediyeye bağlayan düzenleme. 5393/11, özellikle 5026, 5747 ve } 6360 \\
\text { sayılı Kanunların ilgili düzenlemelerine kimi benzerliklerle katılacak belediyenin } \\
\text { ve/veya köyün rızası almadan ana belediyeye katılmasını sağlamaktaydı. } \\
\text { Katma işlemini başlatan ve tamamlayan aktörler tablodaki diğerlerinden çok farklı. }\end{array}$} \\
\hline $\begin{array}{l}\text { Gay } \\
\text { bütü } \\
\text { bele } \\
\text { den } \\
\text { Türl } \\
\text { büti }\end{array}$ & $\begin{array}{l}03 \\
\text { Ali Aygören, } \\
\text { Merkez İlçedeki } 14 \text { belde } \\
\text { sinin başkanları, Bülent Ecevit } \\
\text { ınlığındaki koalisyon hükümeti }\end{array}$ & $\begin{array}{l}\text { Türkiye'de } \\
\text { ş1. Sadece } \\
\text {, } 2001 \\
\text { ün de az }\end{array}$ & $\begin{array}{l}\text { Başkan Ali Aygören'in büyükşehir } \\
\text { belediyesi umudu azalınca Denizli } \\
\text { kentini oluşturan belediyelerden } \\
\text { çoğuyla (14 belediye) arası işbirliğine } \\
\text { dair önerisi ve ortak meclis denemesi }\end{array}$ & $\begin{array}{l}\text { Bütünşehir belediyesine dair Türkiye'deki } \\
\text { ilk açıklamalar: Ali Aygören. } 14 \text { belediyeyi } \\
\text { Denizli Belediyesi ile ilişkilendirip } \\
\text { bütünleştirme fikri zamanla kısmen kabul } \\
\text { görmüşür. } 5026 \text { S. Özel Kanun Teklifini } \\
\text { etkilemiştir denebilir. }\end{array}$ \\
\hline $\begin{array}{l}\text { Veto edilen } \\
5026 \text { sayılı özel } \\
\text { kanunla } \\
\text { bütünşehir } \\
\text { denemesi }\end{array}$ & $\begin{array}{l}\text { Aralık } 2003 \\
\text { AK Partili Denizli Milletvekilleri } \\
\text { AK Parti Hükümeti, } \\
\text { T.B.M.M., } \\
\text { 10. Cumhurbaşkanı A. Necdet Sezer }\end{array}$ & $\begin{array}{l}\text { le bütünşehir } \\
\text { r ve yaygin; } \\
\text { irkiye'de Denizli } \\
\text { ütünşehir terimi } \\
1 \text { halen yok }\end{array}$ & $\begin{array}{l}\text { birkaçı } \\
\text { leşimin } \\
\text { ğlanması } \\
\text { i }\end{array}$ & $\begin{array}{l}5026 \text { sayılı Denizli’ye özel Kanun (Teklifi). } \\
\text { Halk, yereldeki yöneticiler ve medya Teklife } \\
\text { "Bütünşehir Yasası" dedi. Veto edilen } \\
\text { Kanuna göre } 25 \text { köy ve } 22 \text { belediye Denizli } \\
\text { Belediyesinin mahalleleri olacaktı. }\end{array}$ \\
\hline $\begin{array}{l}5216 \text { sayılı yeni } \\
\text { Büyükşehir } \\
\text { Belediye } \\
\text { Kanunu geçici } \\
\text { madde (çember) } \\
\text { düzenlemesi } \\
\text { yoluyla } \\
\text { bütünşehir }\end{array}$ & $\begin{array}{l}2004 \text { yılındaki } 5216 \text { sayılı BşB Kanunu } \\
\text { 200’de unutulan hükümler başlıklı } \\
5390 \text { sayılı Kanunla büyükşehir } \\
\text { sınırlarının } 2 \text { yıl içinde BşB meclisleri } \\
\text { kararıyla zikzaklı hale getirilmesi. } \\
\text { Dönemin AK Parti Hükümeti ve } \\
\text { İçişleri Bakanlığı, Milletvekilleri, } \\
\text { TBMM, İzmir Büyükşehir Belediyesi }\end{array}$ & $\begin{array}{l}\text { Yok, çünkü Denizli } \\
\text { henüz BşB değil. } \\
\text { Türkiye'de yeni bir } \\
\text { bütünşehir terimi var. } \\
\text { Büyükşehir belediyeleri } \\
\text { 20, 30, 50km ve il sınırı } \\
\text { alan genişlemesi, İzmir } \\
\text { Selçuk Belediyesi itirazı. }\end{array}$ & $\begin{array}{l}\text { Yerel yönetim reformunun bir parças1 } \\
\text { olarak } 3030 \text { sayılı } 1984 \text { yılındaki BşB } \\
\text { Kanunu yeniden yazıllyor. 5216'da } \\
\text { bütünşehir tasavvuruna yol açan } \\
\text { düzenleme BşB sınırlarının } 20,30,50 \\
\text { km yarıçaplarla genişlemesi ve bu } \\
\text { yeni sınırlara yeni ilçelerin girmesi }\end{array}$ & $\begin{array}{l}\text { İzmir'de Aliağa ve Selçuk Belediyeleri } \\
\text { bütünşehir'in parçası olmak istemiyor; } 5216 \\
\text { sayılı BşB Kanununun şehri genişletip suni } \\
\text { şekilde bütünleştirdiğini iddia ediyor ve } \\
\text { İzmir BşB'den ayrılmak istiyor. Diyarbakır } \\
\text { ve Mersin gibi illerde de bütünşehir genelde } \\
\text { genişleyen BşB'ye katılmak istemeyen ilçe } \\
\text { ve belde belediyelerinden çıkıyor. }\end{array}$ \\
\hline 5393 Sayıl1 & $2005,2006,2009$. & 5393 sadece Denizli'de & 5393 say1lı Belediye Kanununa 11. & 5393 sayılı Kanunun 11/1. maddesi: Sinır \\
\hline
\end{tabular}




\begin{tabular}{|c|c|c|c|c|}
\hline $\begin{array}{l}\text { Belediye } \\
\text { Kanununun } \\
\text { 11/1. Maddesine } \\
\text { uygulamasiyla } \\
\text { genişleyen } \\
\text { Denizli } \\
\text { Belediyesi }\end{array}$ & $\begin{array}{l}\text { 2005: Belediye Kanunu (5393) } \\
\text { 2006: } 8352 \text { sayılı sınır tespiti kararı } \\
\text { 2009: tüzel kişiliğin sona erdirilmesi. } \\
\text { Denizli Belediyesi } \\
\text { İçişleri Bakanlığı } \\
2014 \text { yerel seçimleriyle anlamsızlaştı. }\end{array}$ & $\begin{array}{l}\text { yeni bir bütünşehir. } \\
\text { Aynı düzenleme nadiren } \\
\text { var; örneğin, çok sayıda } \\
\text { civar köyü mahalle } \\
\text { olarak katılan Kütahya, } \\
\text { ancak bütünşehir terimi } \\
\text { yok }\end{array}$ & $\begin{array}{l}\text { madde olarak eklendi. Kanunun } \\
\text { gerekçesinde adı geçen Denizli bu } \\
\text { maddeyi ilk ve en kapsamlı } \\
\text { kullananlardan birisi oldu. } 5293 \text { sayılı } \\
\text { Kanunun 11/1'in kullanımı hakkında } \\
\text { detay bilgi için: Arıbboğa, 2008a; } \\
\text { 2008b; Özgür, 2008b. }\end{array}$ & $\begin{array}{l}\text { tespiti kararı (üçlü kararname) } \\
\text { Denizli'de ana belediye ve sınırlarına 10km } \\
\text { mesafede Başkarcı hariç, } 12 \text { belediye ve } 10 \\
\text { köy büyükşehir belediyesi kurmayı } \\
\text { kolaylaştırma ve idari parçalanmayı azaltma } \\
\text { amacıyla, 2009 Yerel Seçimleriyle, Denizli } \\
\text { Belediyesi'nin mahallesine dönüştü. }\end{array}$ \\
\hline $\begin{array}{l}\text { Denizli } \\
\text { Büyükşehir } \\
\text { Belediyesine } \\
\text { geçiş hazırlığı }\end{array}$ & $\begin{array}{l}\text { Haziran } 2012 \text { - Aralık } 2012 \\
\text { Başbakan (il mülki sınırında BşB ve } \\
\text { nüfus şartı) } \\
\text { İçişleri Bakanlığı (kanun tasarısı } \\
\text { hazırlığı) } \\
\text { AK Parti Hükümeti } \\
\text { T.B.M.M. }\end{array}$ & $\begin{array}{l}6360 \text { sayılı Kanunun } \\
\text { sonucu olarak var. } \\
6360 \text { sayılı Kanun } \\
\text { sonucu Türkiye'de } \\
\text { uygulaması çok yaygın, } \\
\text { söylemi yaygın. }\end{array}$ & $\begin{array}{l}2011 \text { yılı genel seçimlerindeki AK } \\
\text { Parti söylemi ve sözü il sınırlarında } \\
750.000 \text { nüfus şartını karşılayan } \\
\text { illerin büyükşehir belediyesi } \\
\text { olmasına yönelikti. } 2012 \text { yılındaki } \\
6360 \text { sayılı Kanunla Denizli ve } 12 \text { il } \\
\text { daha il sınırında BşB statüsü kazandı. }\end{array}$ & $\begin{array}{l}6360 \text { sayılı Kanun ve onu tamamlayan } 6449 \\
\text { sayılı Kanun. Kasım } 2012 \text { ve Mart } 2013 \text {. } \\
\text { Tam yürürlük Mart } 2014 \text {. } \\
\text { Denizli ve } 13 \text { ili daha il sınırında büyükşehir } \\
\text { belediyesi yaptı. Bütünşehir } 11.868 \\
\text { kilometrekarelik geniş bir alanı (il } \\
\text { sınırlarını) kapsamaktadır. }\end{array}$ \\
\hline $\begin{array}{l}\text { Köy, köylere } \\
\text { hizmet götürme } \\
\text { birliği (KHGB) } \\
\text { ve il özel } \\
\text { idaresiz Denizli } \\
\text { Büyükşehir } \\
\text { Belediyesi (ve } \\
\text { diğer } 29 \text { ildeki } \\
\text { BşB'ler) }\end{array}$ & $\begin{array}{l}\text { 31 Mart } 2014-\text { devam ediyor } \\
\text { Sürecin ilk günlerinde Denizli } \\
\text { Valiliğinde komisyon } \\
\text { Denizli Büyükşehir Belediyesi } \\
\text { Denizli Büyükşehir Belediyesinin ilçe } \\
\text { belediyeleri } \\
\text { Denizli Su ve Kanalizasyon İdaresi } \\
\text { (DESKİ) } \\
\text { Denizli Valiliği, YİKOB }\end{array}$ & $\begin{array}{l}\text { Denizli’de Türkiye ile } \\
\text { ortak bir bütünşehir } \\
\text { terimi kullanımı var: İl } \\
\text { mülki sınırında BşB. } \\
\text { Türkiye'de bütünşehir } \\
\text { terimi kullanımı hayli } \\
\text { yaygın. BşB olamayan } \\
\text { Elazığ, Sivas, vs. için de } \\
\text { bütünşehir söylemi var. }\end{array}$ & $\begin{array}{l}\text { Bu yeni tip bütünşehir } 6360 \text { sayılı } \\
\text { Kanunun çeşitli hükümlerinin bir } \\
\text { ürünüdür ve ilk kez hem Denizli’yi } \\
\text { hem de başka yerleşimleri birlikte } \\
\text { kapsar, hatta Denizli söylemde } \\
\text { ikincildir. Sadece Denizli’de değil } \\
\text { Türkiye'deki eski ve yeni toplam } 30 \\
\text { büyükşehir belediyesinin hepsinde } \\
\text { sınırlar il mülki sinırı oldu. }\end{array}$ & $\begin{array}{l}\text { 6360'ın Resmi Gazetede yayımlandığı } \\
\text { Aralık 2012'den Mart } 2014 \text { yerel } \\
\text { seçimlerine kadar geçiş süreci oldu. Bu } \\
\text { dönemde ilçeler kuruldu veya isim değiştir. } \\
\text { Nisan 2014'den itibaren belde belediyeleri } \\
\text { ve köyler mahalle oldu. Denizli Su ve } \\
\text { Kanalizasyon İdaresi Genel Müdürlüğü } \\
\text { kuruldu. Artık il özel idareleri de Denizli'de } \\
\text { ve diğer büyükşehir belediyelerinde yoktur. }\end{array}$ \\
\hline
\end{tabular}

Tablo 5: Denizli'de Uygulanmayan ama Türkiye'de Örnekleri Olan Bütünşehir (Belediyesi) Tasavvurları ve Uygulamaları

\begin{tabular}{|l|l|l|l|l|l|}
\hline & Bütünşehir (Belediyesi) Tanımı ve Temel Özellikleri (Kısaca) & $\begin{array}{l}\text { Bütünşehir } \\
\text { söylemi adı }\end{array}$ & Dönemi & İlçe sayıs1 & İlçe sayıs1 \\
\hline & Denizli bütünşehir tasavvuru: --, Denizli dışı Türkiye bütünşehir tasavvuru: 1 & $2004-2008$ & $2008-2012$ \\
\hline 1 & $\begin{array}{l}\text { 5216 sayılı Kanunla büyükşehir belediyelerinde 20, 30, 50 km sınır } \\
\text { genişlemesi, İstanbul ve Kocaeli il sınırlarında büyükşehir belediyesi }\end{array}$ & $\begin{array}{l}\text { Çember } \\
\text { düzenlemesi }\end{array}$ & $\begin{array}{l}07.2004- \\
03.2014\end{array}$ & 101 \\
\hline
\end{tabular}

Tablo 6: Denizli’de Bütünşehir (Belediyesi) Tasavvurları: Tanımları ve Kapsadıkları Köyler ile Belediyeler

\begin{tabular}{|c|c|c|c|c|c|}
\hline & \multirow{2}{*}{$\begin{array}{l}\text { Bütünşehir } \\
\text { tasarımının adı }\end{array}$} & \multirow{2}{*}{$\begin{array}{l}\text { Dönemi: } \\
\text { Ay ve y1 }\end{array}$} & \multicolumn{3}{|c|}{ Bütünşehire dahil } \\
\hline Bütünşehir (Belediyesi) Tanımı ve Temel Özellikleri (Kısaca) & & & İlçe sayıs1 & Belediye say. & Köy sayıs1 \\
\hline
\end{tabular}


Denizli bütünşehir tasavvuru: 1, Denizli dışı Türkiye bütünşehir tasavvuru: 0

1 Bütünşehir belediyesine dair Türkiye'deki ilk açıklamalar ve çabalar

(gönüllü ortak meclis temeline dayalı): Başkan Ali Aygören

Gayrı resmi ve

Denizli bütünșehir tasavvuru: 2, Denizli dıșı Türkiye bütünșehir tasavvuru: 0

2 Aralık 2003'de çıkarılıp yerel seçimlere dair tali sebepten veto edilen

5026 sayılı Denizli’ye özel "Bütünşehir Kanunu" Teklifi c1lız bütünşehir

$01.2001-$

12.2003

1: Merkez

$15(1+14)$

0

Özel kanunla

12.2003- 3 : Akköy,

$23(1+22)$

Denizli bütünșehir tasavvuru: 3, Denizli dıșı Türkiye bütünșehir tasavvuru: 1

5393 sayıl1 Kanunun 11/1. Maddesi: Sınır tespiti (13 belediye ve $10 \quad$ 5393/11'de

07.2004 Honaz, Mrk

köyün Denizli belediyesine bağlanması) (üçlü kararname) kararı süreci Denizli. Öncü

5393 sayılı Kanunun 11/1. Maddesine göre sınır tespiti (12 belediye ve

10 köyün Denizli Belediyesine bağlanması) kararının uygulanması

5393/11 Denizli

Not: 5393 sayılı Kanunun 8. Maddesi ile Denizli Belediyesine katılım

uygulamas

$07.2004-$

03.2009

04.2009

Denizli bütünşehir tasavvuru: 4, Denizli dışı Türkiye bütünşehir tasavvuru: 2

6360 sayılı Kanunla 2014 yerel seçimlerinde tam olarak geçerli olacak

4 büyükşehir belediyesi kararı ve hazırlıkları

6360 sayıl1 Kanun uygulaması sonucu yeni durum $(11.868$ km²'lik il

sınırlarında Denizli Büyükşehir Belediyesi)

Denizli BşB'ne

03.2014

2009

\begin{tabular}{|l|l|l|}
\hline $1:$ Merkez & $14(1+13)$ & 10 \\
\hline $1:$ Merkez & $13(1+12)$ & 10 \\
\hline $1:$ Merkez & Cankurtaran & - \\
\hline
\end{tabular}

\begin{tabular}{l|l|l|l}
$11.2012-$ & $19,18-1+2:$ & $19(82-65+1)$ & 359 \\
\hline
\end{tabular}

geçiş hazırlığ1

İÖİ'siz Denizli

04.2014

$19 \mathrm{BşB}$

$1+19=20 * * * \quad 0$

* Denizli sınırlarındaki (başlangıç yılı esas alınarak)

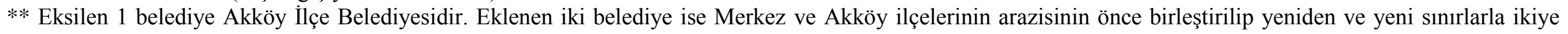
bölünmesinden doğan Merkezefendi ve Pamukkale'dir.

*** Toplam 1 büyükşehir belediyesi ve 19 büyükşehir ilçe belediyesinden müteşekkil olmak üzere 20'dir. 
Tablolardan görüleceği üzere, bütünşehir tasavvurlarının ve ondan önce benzer etkiler gösteren mücavir alan düzenlemelerinin kapsadığı yerleşim birimi sayısı ve türünde ciddi farklılıklar bulunmaktadır. Uygulanması zor ve siyasi maliyetleri olabilecek 5393 sayılı Belediye Kanununun 11. maddesinin Denizli'de uygulanması için üçlü Kararname, Hallaçlar Belediyesi hariç, 12 belediye ve 10 köyün Denizli Belediyesine mahalle olarak bağlanıp 3. tip bütünşehir tasavvurunun/tasarımının hayata geçmesiyle sonuçlandı. Denizli Belediyesini çevreleyen irili ufaklı belediyelerin ve köylerin varlığı, Denizli'nin merkeze sıkışmasına ve büyüme şansının hayli azalmasına sebep oldu. 2007 yılında onaylanan revize 1/25.000 ölçekli Denizli İl Çevre Düzeni Planı'nın Gerekçesinde (sayfa 6) kentteki idari bölünmenin planlamayı güçleştirmesi ifade edilmekteydi:

Sanayinin başat sektör olduğu diğer tüm kentlerimizdeki gibi, Denizli’nin de yaşadığı en ciddi sorun, planların, hızlı kentsel gelişmenin gerisinde kalmış olmasıdır. Bu sorunlu yapıya, idari yapılanma açısından ortaya çıkan bölünmenin getirdiği açmazlar da eklendiğinde, bugün, gerçek anlamda bir planlı gelişimin sağlanması neredeyse olanaksız hale gelmiştir. Planlama çalışması yapılan bölgede (ki, bu bölge, Doğu-Batı doğrultusunda 30, Kuzey-Güney doğrultusunda 20 km'lik bir sahadır) içerisinde, Denizli Belediyesi dışında 19 ayrı belediye erkinin olması ve bu erkin sağladığı yetki ile plan kararı üretilmesi ... plansızlığa ... temel oluşturmaktadır.

Türkiye'de hiçbir hukuki mevzuatta, doğal olarak 5026, 5393, 5216, 5747 ve 6360'da, "bütünşehir" terimi kullanılmadı. Denizli'de, 2001-2014 döneminde birbiriyle ilintili dört farklı bütünşehir tasavvuru ortaya çıkmıştır. Denizli'de 1976-1989 dönemindeki kapsamlı mücavir alan düzenlemesi de içerik ve amaçlar açısından bütünşehir belediyesi tasavvurlarına benzerlikler göstermektedir. Bu bütünşehir tasavvurlarının (i) ortaya çıkışının nedenleri, (ii) anlamı ve gelişımi, (iii) hukuki düzenlemeler, (iv) lehinde ve aleyhindeki söylemler bu çalışmanın ana konusudur. Yukarıda Denizli kentsel alanının parçalanmışlığı ve bütünşehir tasavvurları özetlenmişti. Aşağıda birbiriyle ilintili bütünşehir tasavvurlarının Denizli'deki gelişimi detaylıca hikâye edilmekte ve irdelenmektedir.

\section{BİRINCI TASAVVUR: DENIZLİ BELEDIYE BAŞKANI ALİ AYGÖREN'İN KOMŞU BELEDIYYLERLE ORTAK KARAR VERME OLARAK BÜTÜNŞEHİR (2001)}

1999-2004 dönemi Denizli Belediye Başkanı Ali Aygören Ocak 2001'de Türkiye'de bütünşehir terimini ilk kez kullanmıştır. Aygören bütünşehiri "ilçe belediyeleri olmadan tek belediye meclisi çatısı" olarak tanımlamıştı. Aygören, 14 belediyeyi kapsayacak Denizli özelindeki bu modelle kentle ilgili tüm kararların bütünşehir belediye meclisinde alınmasını, hizmetlerin tek elden yürütülmesini tasavvur etmişti.

Hürriyet Gazetesinin Ege Ekinde 02.01.2001 tarihinde "Büyükşehir out bütünşehir başlığıyla verilen haberde "bütünşehir" terimiyle ilk kez karşılaşılmaktadır:

Denizli Belediye Başkanı Ali Aygören, "büyükşehir" sevdasından vazgeçti, "bütünşehir”i savunmaya başladı. Bütünşehiri, “... tek belediye meclisi çatısı” diye tanımlayan Aygören, modeli kamuoyunda tartışmaya açacaklarını söyledi. Bu modelde kentle ilgili tüm kararların bütünşehir belediye meclisinde alınacağını, hizmetlerin tek elden yürütüleceğini ve vergilerin de bütünşehir belediyesince toplanacağını belirten Aygören, "böylece, büyükşehirin sıkıntıları ortadan kalkacak" dedi. Bütünşehir gerekçelerini anlatan Aygören, "Denizli'de 554 sanayi kuruluşu var, biri bile bizim mücavir alanımızda değil. Tümü vergilerini çevre belediyelere ödüyorlar. Köyü belde yapıyorsunuz, dokuz kişi [az nüfuslu her belediyedeki meclis üyeleri] o beldenin kaderini belirliyor" diye konuştu.

Akşam Gazetesinin 31.01.2001 tarihli Ege Ekinde "Yaşasın Bütünşehir!" başlıklı haber de Ali Aygören'in bütünşehir terim ve söylemini bölgesel medyaya taşımıştır:

Denizli'nin yıllardır gündemini işgal eden büyükşehir özlemi suya düşünce yerini 'Bütünşehir' projesi aldı. Belediye Başkanı Ali Aygüren'in konu ile ilgili projesine önce karşı çıkan 14 belde başkanı daha sonra olumlu yaklaşım gösterdi. Bütünşehir projesine İmar İşleri'nden başlanacağı açıklandı. Bütünşehir projesi çerçevesinde ilk olarak imar uygulamalarının birleştirileceğini yineleyen Aygören, '14 belde 
başkanıyla vardığımız anlaşma sonunda yapılaşmanın düzenli ve sağlıklı yürütülmesi için yoğun çalışma başlattık' diye konuştu.

Denizli Merkez İlçede belediyelerin ortak çalışma ürünü önemli projeler 2001 öncesinde başladı: 1) Kentsel katı atıkların bertarafında ortak kullanılan Kumkısık Köyü karşısındaki düzenli depolama alanı, 2) 1994 yılında yapılan 1/25.000'lik çevre düzeni planı, 3) Korucuk Belediyesi yönündeki ortak atıksu arıtma tesisi. Bu tesis ve faaliyetlere protokolle katılan belediye sayısı da zamanla artmıştır. 1/25.000'lik plan 18 belediyenin protokolle Denizli Belediyesine verdiği yetkiyle 1994'te onaylandı. Plana rağmen çarpık kentleşmenin devam ettiği ve hızlı göç alan Denizli’nin bu planı yeni bir protokolle Denizli Belediyesince 2005'te revize edildi (Özgür, 2007; Özgür, Savaş Yavuzçehre, 2007a; 2007b; Ciğeroğlu; 2007; Savaş Yavuzçehre, 2011).

TMMOB Mimarlar Odası Denizli Şubesince düzenlenen "Büyükşehir Deneyimleri Ișığında Denizli" Panel ve Forumunda konuşan dönemin (1999-2004) Belediye Başkanı Ali Aygören şunları ifade etmekteydi:

Denizli, kentsel özelliğini yitirmiş ve gerçekten büyük bir karmaşa oluşmuş. Yetki karmaşası bugün de var ve yarın da olmaya devam edecektir. Kolu, bacağı alınmış, sadece gövdesi kalmış bir insan konumundayız. Sakın yanlış anlaşılmasın; bütün belediye başkan arkadaşlarımızla bir sorunumuz, bir uyumsuzluğumuz yok. Aksine, 'Denizli büyükşehir olmalıdır, aksi takdirde kurtulması mümkün değildir. Eğer, büyükşsehir olamıyorsa bunu birlikte yönetelim ve yönetirken de bütün şehir [bütünşehir] olarak hareket edelim' görüşünü paylaşıyoruz. Bu görüş Tasarının ek 21. maddesine de yeni bir hüküm olarak eklendi. İnşallah, Yerel Yönetimler Yasası geçerse, söylediklerimizin büyük bölümü orada da yer alacak ve Denizli bundan nasibini alacak.

Aygören'in son cümlesindeki Tasarı ve onun Ek 21. maddesi bütünşehir tasavvurlarına başlangıçtır. "2000 Yerel Yönetimler KHK Tasarısı” olarak da anılan "Merkez İdareyle Mahalli İdareler Arasında Görev Bölüşümü ve Hizmet İlişkilerinin Esasları İle Mahalli İdarelerle İlgili Çeşitli Kanunlarda Değişiklik Yapılmasına Dair KHK” Tasarısının Ek Madde 21 hükümleri 2004-2005 yıllarındaki 5215-5272-5393 sayılı Belediye Kanunlarının 11. maddesiyle hayli benzeşir. 5393 sayılı Kanunun 11/1. maddesi bu yazının ilerleyen bölümlerinde irdelenen bütünşehir tasavvurudur; Ek Madde 21 şöyledir:

Gelirlerinin belediye hizmetleri için yetersiz hale gelmesi, nüfuslarının 2000'in altına düşmesi, meskûn sahalarının bağlı oldukları il veya ilçe merkez belediyelerinin meskûn sahalarına 5000 metreden daha yakın hale gelmesi ve genel imar düzeni veya temel alt yapı hizmetlerinde bütünlüğün sağlanması bakımından zorunluluk bulunması durumlarından bir veya birkaçının ortaya çıkması halinde, İçişleri Bakanlığının teklifi ve Bakanlar Kurulu kararıyla belde belediyelerinin tüzel kişilikleri kaldırılarak bağlı oldukları ile veya ilçe merkez belediyelerine katılabilirler, bunun mümkün olmaması halinde köy haline getirilebilirler. Katılma halinde, katılan belediyenin mahalleleri katıldıkları il veya ilçe merkez belediyesinin mahalleleri haline gelir ve personel, kadro, taşınır ve taşınmaz mal, hak, alacak ve borçları bağlandıkları belediyeye intikal eder. ... Bu madde gereğince Bakanlar Kurulunca verilecek belediye kaldırma kararları, ilk mahalli idareler genel seçimleri tarihinde hüküm ifade eder ve kaldırılan belediyelerin katıldıkları belediyelerde veya kaldırılan belediye yerine kurulan köylerde seçimler, bunların yeni statülerine göre yapılır. [Paragraflar birleştirilmiştir].

2000 Yerel Yönetimler KHK Tasarısına bizzat katkı veren Ali Aygören'in de çabalarıyla Tasarıya eklenen Ek Madde 21 bütünşehir tasavvurlarının öncülerindendir. Yerel gazeteci Yasin Efesoy, 5747 sayılı ve Mart 2008 tarihli Kanunun yasalaşma döneminde 29.01.2008 tarihinde başlatılan "Az nüfuslu yerlerin belediyeleri kapatılmalı mı?" başlıklı haberde şunları yazıyordu (www.wowturkey.com):

Konuyla ilgili en yakın örneği Denizli'den vereceğim. Malumunuz Denizli'de bir "bütünşehir" tartışması var. Temeli 2000 yılında dönemin belediye başkanı Ali AYGÖREN tarafindan atılan ve 2006'da da 
belediye başkanı Nihat Zeybekci'nin girişimiyle tekrardan ... [gündeme getirilen husus] 5393 Belediye Kanununun 11. Maddesi ...[nde düzenlenmiştir.] ... Denizli Belediyesi çevresinde, en fazla 5000 metre mesafedeki belediye ve köyler Denizli Belediyesi’ne bağlanmıştır. Burada nüfus kriteri gözardı edilmiştir. Çünkü bu alt yönetimler, Denizli Belediyesi’ne hep ayak bağı olmuşlardır. Yerinde bir karar. ... Ve birçoğu da Denizli Belediyesi mücavirinde.

Aygören AK Partinin 5026 sayılı Kanun (Teklifine) yansıyan yeni bir bütünşehir teklif ve tasavvurunu prensip olarak desteklemekteydi. Aygören, Yeni Asır Gazetesi, 5026 sayılı Denizli’ye özel Bütünşehir Kanun (Teklifinin) veto edilmesinin ardından, 16 Ocak 2004'deki röportajında yeni bütünşehir tasavvurunu değerlendirmekteydi:

Bence Denizli, şu son zamanlarda gündeme gelen bütünşehir projesine karşı çıkmakla hata etti gibi geliyor. En azından sizin de zaman zaman şikâyette bulunduğunuzu bildiğim plan bütünlüğünü sağlamak açısından bütünşehir iyi bir projeydi. Bizim amacımız, yıllardan beri büyükşehirdi. Sonra böyle bir kanun teklifi ortaya atıldı. Ama biz, çevremizde yer alan 22 belediyenin başkanı ile bir çevre düzeni protokolü imzalamıştık. ... Bu tamamen iyi niyete dayalı bir anlaşma. Dileyen dilediği an karşı çıkabilir. Oysa bütünşehir yeni bir yapılanma getiriyordu. Ama onun da eksikleri vardı. Kanun teklifi hazırlanırken, bizden ve belediye meclis üyelerinden görüş alınsaydı, daha iyi olabilirdi. Çünkü biz bu kentin sorunlarını, yaşadıklarını ve gelişmesinin önündeki engelleri ve bunların nasıla aşılabileceğini Ankara'dakilerden daha iyi biliyoruz.

Bütünşehir teriminin yaygınlaşması ancak Aralık 2003'te TBMM'den geçen ancak veto edilen 5026 sayılı "Denizli İline Bağlı Akköy İlçesi ile Bazı Belediye ve Köylerin Tüzel Kişiliklerinin Kaldırılarak Denizli Belediye Sınırları İçine Alınması Hakkında Kanun Teklifi" ile oldu. Teklifi Meclise sunan dönemin AK Parti Denizli milletvekillerinin esin kaynağı Ali Aygören'in Ocak 2001'de bütünşehir tasavvuru olabilir. 2002 sonunda iktidara gelen AK Partinin yerel yönetimler reformuna yönelik hukuki düzenlemeleri esas olarak 2004-2006'da geçerlilik kazandı. Aralık 2003'de Mecliste de çoğunluğa sahip ve hükümet olan AK Parti iktidarı yerel seçimlere ilişkin kalan sürenin yetersizliği gerekçesiyle veto edilen $(5019,5025,5026$ sayılı) üç özel kanun çıkarmıştı. Ulusal düzeyde yoğun ilgi ve tepki toplayan bu kanunlardan birisi mevcut büyükşehir belediyelerini diğeri de nüfusu 2.000 'in altındaki küçük belediyeleri ilgilendirmekteydi. Denizli'ye özel 5026'nın da aynı ayda Meclisten geçip veto edilişi, onun da bölgesel ve ulusal düzeyde yoğun ilgi görmesine sebep oldu.

Aslında, hiçbir hukuki mevzuatta, doğal olarak 5026 ve 5393'de de bütünşehir (belediyesi) terimi kullanılmadı; ancak, 5026 sayılı Kanun (Teklifinin) düzenlemesi ve 5393'ün 11. maddesi 1. fikrasının uygulanması çabası Denizli'de bütünşehir terimiyle özdeşleşmiştir. Bütünşehir (belediyesi) teriminin kısa zamanda benimsenip yaygınlaşmasında itibarlı ve iyi bilinen büyükşehir teriminin yaygın kabul ve bilinirlik düzeyi ile bütünşehir'in büyükşehir'e benzemesi de etkilidir.

Nüfusu 2.000'in altındaki belediyelerin köy statüsüne döndürülmesini öngören iki Kanun önerisi Aralık 2003'te (5025) ve Şubat 2008'de (6747) TBMM'nden geçti. 5025 sayılı "Bazı Belediyelerin Kaldırılması Hakkında Kanunu" 10. Cumhurbaşkanı Meclise geri gönderdi. Şubat 2008'de yasalaşan ve esas itibariyle Mart 2009 yerel seçimleriyle uygulanan 5747 sayılı özel Kanunun ilk ekseninde nüfusu 2000 altındaki çok sayıda belediyenin kapatılması düzenleniyor, ikinci ekseninde ise büyükşehir belediyelerinde yeni ilçeler kuruluyordu. Her iki eksen de uygulandığı yerleşim öbeklerinde parçalanmayı azaltıcı idi ve bütünşehir tasavvurlarına benzer etkiler meydana getirdi.

5215 (Temmuz 2004) ve 5272 (Aralık 2004) sayılı Kanunları 5393 (Temmuz 2005) sayılı Belediye Kanunu takip etmektedir. Her üç Kanunun da 11. maddesi 1. fikrası bütünşehir tasavvuru ve uygulamasının yeni bir içerikle hem Türkiye çapında hem de Denizli özelinde tekrar gündeme gelmesine yol açmıştır. 5393'ün 11/1. Maddesi belediyelerde optimal büyüklüğü yakalamayı ve parçalanmayı azaltmayı amaçlar. 5215-5272-5393 sayıl1 Belediye Kanunlarına eklenen kimi geçici maddeler ile 4. ve 5. maddeler idari parçalanmayı ve yeni belediye oluşumunu yavaşlatıcı etkiler gösterirken 8 . ve 11. maddeler ile geçici 3 . maddedeki düzenlemeler ise kentsel alanlarda idari parçalanmayı azaltabilmektedir. 


\title{
4. İKINCI TASAVVUR: ARALIK 2003'TEKI 5026 SAYILI -VETO EDÍLEN- 47 YERLEŞIMI DENIZLII BELEDIYESININ MAHALLESI YAPMAYI ÖNGÖREN ÖZEL KANUN YOLUYLA BÜTÜNŞEHIR
}

Aralık 2003'de Meclis'ten geçip 10. Cumhurbaşkanı Sezer'in seçime ilişkin tali bir nedenden geri gönderdiği 5026 sayılı Kanun (Teklifi) akademik alanyazına birkaç istisna dışında (örneğin, Ciğeroğlu, 2007; Özgür ve Kösecik, 2006; Özgür, 2007; 2008b; 2012; Savaş Yavuzçehre, 2011) pek taşınmamıştır. 5026 sayılı Kanun Teklifinin ortaya çıkışı, gerekçesi, maddeleri, lehinde ve aleyhindeki görüşler ve bütünşehir söylemi aşağıdadır.

"Bütünşehir Yasası" olarak da anılan 5026 sayılı "Bazı Belediye ve Köylerin Denizli Belediyesine Katılmasına İlișkin Kanun" Teklifini 22. Dönemin dört Denizli Milletvekili 10.12.2003 tarihinde "Denizli İline Bağlı Akköy İlçesi ile Bazı Belediye ve Köylerin Tüzel Kişiliklerinin Kaldırılarak Denizli Belediye Sınırları İçine Alınması Hakkında Kanun Teklifi” adıyla TBMM'ye sundu. Meclisten geçip veto edilen Kanun Taslağı ile ilk önerilen Taslağın başlıkları farklıdır. Taslağın Gerekçesinde Denizli kentsel alanının durumu şöyledir:

\begin{abstract}
Denizli ve civarında başta yatırım faaliyetlerinin gerçekleştirilmesi olmak üzere yerel hizmetlerin sunumunda önemli sıkıntılar yaşanmaktadır. İl merkez belediyesinin etrafinda yirmiden fazla belediye olması planlama ve koordinasyon hizmetlerini aksatmakta, uygulamada karmaşıklığa meydan vermektedir. Belediyelerin komşu olması nedeniyle imar planları yapılması ve mücavir alan uygulaması birbirine zıt olmakta, aynı alanda farklı uygulamalar vatandaşları, yatırımcıları ve hizmet talep edenleri sıkıntıya sokmaktadır. Örneğin bir organize sanayi bölgesi yer seçimi bile önemli engellerle karşılaşmaktadır. İlin gelişimi dikkate alındığında, bölgede planlama, koordinasyon ve uygulamada bütünlüğün sağlanması önem arz etmektedir. Bu nedenle Denizli Belediyesi etrafındaki belediye ve köylerin Denizli Belediyesine katılması gerekmektedir.
\end{abstract}

İçişleri Komisyonu 15.12.2003'de Teklifin lehinde ve aleyhinde görüşler oluşturdu. Denizli'nin çok önemli bir sanayi ve turizm merkezi olduğu, İl'in hızla geliştiği ve bu nedenle çevre illerden yoğun göçe maruz kaldığ 1 , hızla büyüyen kentin mevcut yerel yönetim yapısıyla hizmet sunmada yetersiz kaldığ 1 , Merkez İlçedeki 22 belediyenin bütünsel planlama yapmasının olanaklı olmadığı, sivil toplum örgütleri ve halk tarafından da desteklenen bu Teklifin bir an önce yasalaşması gerektiği Komisyon'ca oluşturulan lehte görüşlerdi. Teklifin aleyhindeki görüşe göre Denizli için düzenleme gerekli olmakla birlikte bu bilimsel temele dayalı ve STK'ların katılımıyla yapılmalıdır. Seçmen kütükleri askıya çıkarıldıktan sonra Teklifin düzenlemesi seçim hesapları taşımaktaydı. İçişleri Komisyonu yeni metninde Teklifin adını "Bazı Belediye ve Köylerin Denizli Belediyesine Katılmasına İlişkin Kanun" olarak değiştirdi. Teklifin yeni 1. Maddesine göre Merkez, Honaz, Akköy, Sarayköy ve Babadağ İlçelerindeki 22 belediye ve 25 köyün tüzel kișilikleri kaldırılarak onların taşınır ve taşınmaz malları; hak, alacak ve borçları; personel, kadro ve bütçeleri Denizli Belediyesine devredilecekti.

28 Mart 2004 yerel seçimlerinin üç ay öncesinde Aralık 2003'te 10. Cumhurbaşkanı A.N. Sezer'in onayına sunulan 5026 sayılı Denizli’ye özel Yasa seçimlerle ilgili süre tali sebebinden dolayı veto edildi.

03.10.2001 günlü, 4709 sayılı Yasanın 24. maddesiyle Anayasa'nın 67. maddesine eklenen son fikrada, seçim yasalarında yapılan değişikliklerin, yürürlüğe girdiği günden başlayarak bir yıl içinde yapılacak seçimlerde uygulanmayacağını kurala bağlandığını anımsatan Sezer, bu kural kapsamında bulunan seçim yasalarında yapılan değişikliklerden kastın anlaşılabilmesi için, kuralın getiriliş amacına bakılması gerektiğini ifade etti:

4709 sayılı Yasanın 24. maddesinin gerekçesinde, "yeni eklenen bir fikra ile konjonktürel değişikliklere seçim kanunları açısından yer verilmemesi amaçlanmıștır" denilerek, siyasal dalgalanmaların seçimleri düzenleyen kurallara yansıyıp seçim sonuçlarına etkili olmaması amaçlanmıştır. Bu amaç gözönüne alındığında, doğrudan seçim yasalarını değiştirmese de, bir yasa ile yapılan değişikliğin ya da getirilen kuralın seçimleri ilgilendirip ilgilendirmediğinin, getirilen kuralın seçim yasası değişikliği niteliğinde olup olmadığının incelenmesi gerekmektedir. Bir başka anlatımla, Anayasa koyucunun istencinin tam anlamıyla etkili ve egemen kılınabilmesi için yapılan yasal düzenlemenin niteliğinin ortaya konulması 
gerekmektedir. Bunun için kuralın içeriği ve etkisi üzerinde durulması, eğer metin seçim yasası kurallarına eşdeğer ve etkililikte ise anayasal yönden değerlendirmeye bağlı tutulması zorunlu görülmektedir.' (Hürriyet Gazetesi, 2003: hurarsiv.hurriyet.com.tr)

2001 yılında Anayasa'da seçimlerle ilgili bu ek düzenlemeyi Cumhurbaşkanının 5026'yı değerlendirirken dikkate alarak yorumlaması Kanunun veto edilmesine yol açt1. 30.12.2003'de TBMM Başkanlığına gönderilen veto gerekçesinin sonu şöyledir:

İncelenen Yasa'nın 1. maddesiyle, Yasa'ya ekli (1) sayılı listede adlanı yazılı belediyeler ile ekli (2) sayılı listede adları yazılı köylerin tüzel kişilikleri kaldırılarak bu yerler Denizli Belediyesi’ne mahalle olarak bağlanmakta; geçici 3. maddesiyle de, Denizli Belediyesi'nde yapılan bu sınır değişikliğinin 28 Mart 2004 gününde yapılacak yerel yönetim seçimlerinde uygulanması sağlanmaktadır. Bu içeriğiyle, incelenen Yasa'nın seçimleri etkileyeceği, geçici 3. maddesiyle getirilen kuralın seçimlerle doğrudan ilgili olduğu ve seçim yasası değişikliği niteliğinde bulunduğu görülmektedir. ... İncelenen Yasa'nın genel gerekçesinde özetle, ilin gelişimi göz önünde bulundurulduğunda, bölgede planlama, eşgüdüm ve uygulamada bütünlüğün sağlanmasının önemli olduğu, bu nedenle Denizli Belediyesi çevresindeki belediye ve köylerin bu Belediye'ye katılmasının gerektiği; 1 . madde gerekçesinde de, Denizli Belediyesi sınırlarına bitişik ya da çok yakın olan belediyelerin Denizli Belediyesi içine alınmasıyla ... yetki uyuşmazlı̆̆ının ortadan kaldırılmasının ve belediye hizmetlerinin verimliliğinin artırılmasının amaçlandığı vurgulanmaktadır. ... Bu gerekçe haklı olsa da, ... incelenen 5026 sayılı Yasa'nın geçici 3. maddesi, Anayasa'nın 67. maddesinin son fikrasıyla bağdaşmamaktadır.

Hem Meclise gönderilen Teklif hem de Meclisten geçip veto edilen Kanun bir sayfalık gerekçe, yarım sayfalık metin ve tüzel kişiliği kaldırılacak belediye ve köyleri gösteren ek tablolardan oluşmaktaydı. Önemli bir değişimi başarmak isteyen bu Teklif basit, kısa, acele ve amatördü. TBMM'nin 20.12.2003 tarihli 32 . Birleşimde şahsı adına söz alan dönemin Denizli Milletvekili Mustafa Gazalcı'nın Teklif'le ilgili sözleri şöyleydi:

... biz, Denizli'ye hizmet gelmesini istiyoruz; biz Denizli milletvekilleriyiz. AKP'lilerle, hizmet konusunda her zaman birleşiriz, yani, bir araya geliriz, ... ama, yaptıkları ayıp. Bir gecede 50 belediyemiz alınıyor, Denizli’nin kolu kanadı kırılıyor, büyükşehir olmayı beklerken, bütünşehir oluyor. Böyle bir statü yok, böyle bir olanak yok. Ne demek bütünşehir?! ... ben diyorum ki, bu ne çevre belediyelere ne Denizli Belediyesine yarayan bir şeydir. ... insanların görüşleri alınmamış, bu bir reform değil. ... böyle sabahlara karşı görüştügümüz yasalarda hep yanlışlar yapıllıor, ... Denizlililer 1srarla 'biz, böyle bir değişiklik istemiyoruz, büyükkent olmak istiyoruz' diyorlar. Çünkü Denizli büyükkent olduğu zaman, bu tüzelkişilikleri yok edilen belediyeler varlıklarını koruyacaklar, birinci kademe belediye olacaklar. Kırk yıllık, elli yıllık belediyeler ve Denizli'nin uzağında bir kısmı, tamam, bir kısmı Denizli'yle birlikte; ama planı, programı yapılmış. Hangi açıdan Denizli'ye yarayan bir iş var burada? Büyükşehir mi oluyoruz; hayır. Başka bir gelir mi sağlanıyor; hayır.

5026 sayılı Kanun (Teklifi) Türkiye'de bir daha denenmeyen ve Denizli'ye özel bir hukuki düzenlemeydi. Yerelde hazırlık aşamasında tartışılmadan Meclisten hızlıca geçen bu Teklifin 2004-2005'de tekrar TBMM'ye getirilme talepleri Merkez İlçedeki küçük belediyelerin seçilmiş yöneticilerinin tepkilerine yol açtı. Yerel, bölgesel ve ulusal basına yansıyan haberlere rağmen, Teklif yerel halka yeterince anlatılamadi. Kanun (Teklifi) veto edilmeseydi, Merkez İlçedeki çoğu köy ve belediyelere ilaveten komşu ilçelerin kimi yerleşimleri de, --kısa süre sonra Mart 2004'de yapılan-- yerel seçimlerin ardından, Denizli Belediyesinin mahallelerine dönüşecekti. Kanun 2003 sonunda Denizli Belediyesinin nüfusunu 2 kata yakın artırırken (2000 nüfus sayımı sonuçlarına göre 275.000'den yaklaşık 500.000'e), alanını 9 kat civarında artıracaktı. Çevreyolu, imar planı, toplu konut, mekân kullanımı, yağmursuyu tahliyesi, kentiçi ulaşım, turistik Karahayıt-Pamukkale yöresinin yönetimi sorunlarını hafifletebilecek Kanun (Teklifi) bazı yeni sorunlar da çıkarabilirdi. Genişleyen alanda adaletli hizmet yürütme, Çüruksu Ovasının tarım dışı amaçlarla kullanımı, kapanacak yerel yönetimlerden dolayı demokrasinin ve kendi kaderini tayin ilkelerinin zedelenmesi, yeni rant kavgaları olası sorunlardı. Denizli'de bütünşehir fikri lehte ve aleyhte hayli ilgi gördü ve doğal olarak en çok destek Denizli Belediyesinden geldi. Vatan Gazetesi’nin 14.12.2003 tarihli haberinin son kısmı şöyleydi: 
... Kent belediyeleri için de 'büyükşehir belediyelerinde' olduğu gibi 'yasa teklifi' formülünü kullanan AKP, Denizli merkez belediyesinin yetki kapsamını genişleten bir teklifi Meclis'in gündemine taşıdı. ... teklif, jet hızıyla ilgili Meclis ihtisas komisyonlarına sevk edilerek, gündeme alındı. ... Teklifle ayrica, merkez belediyenin etrafindaki 22 belde belediye başkanlığı ile 29 köy de, aynı şekilde merkez belediyenin yetki sahasına konuluyor. Teklifle kaldırılıp, merkeze bağlanan ilçe ve belde belediyelerinin 11'i DYP, 7'si ANAP'ta bulunuyor. Bu belediyeler arasında MHP ve CHP'nin de 2'şer belediyesi bulunuyor.

Pamukkale, Karahayıt, Gölemezli (Akköy), Yenicekent (Buldan) beldeleri farklı özellikleri içeren kaplıca sularıyla ünlüdür. Ali Aygören'in 1999-2004 belediye başkanlığı döneminde gerçekleşmeyen civardaki sıcak sularla Denizli'yi ısıtma projeleri Denizli kentsel alanını geniş tasavvur ettirmekteydi. İmar, konut ve arsa üretimi, ana yollar, geleceğe yönelik ulaşım imkânları gibi nedenlerle Denizli Belediyesi 1976'dan itibaren çevredeki yerleşimleri kontrol etmeye yönelik mücavir alan, üst ölçekli imar planı, çevre yolları, ortak katı atık deponi alanı işletmesi işlerine girişmişti. Tarım topraklarının kaybı, çarpık yapılaşma, rant, optimal hizmet ölçeği, su kaynaklarının kontrolü gibi unsurlar da Denizli Belediyesi’nin arazi ihtiyacını genişletmekteydi.

Bütünşehir (belediyesi) fikrini ilk defa ortaya atan Başkan Ali Aygören aslında büyükşehir belediyesi statüsü istemekle birlikte umudu azalınca bütünşehir belediyesi fikrini dile getirmişti. 28 Aralık 2003 tarihli Yeni Asır Gazetesi, 5026 sayılı Denizli’ye özel Yasanın Cumhurbaşkanınca geçici 3. maddesinin veto edilmesinden birkaç gün önce dönemin Belediye Başkanı Ali Aygören şunları ifade etmekteydi:

Bütünşehir Yasasının Cumhurbaşkanı Sezer tarafından onaylanmasını isteyen Aygören, ancak Denizli için özel bir yasa çıkarılmasını arzuladıklarını söyledi. Aygören, 'Denizli'nin gelirlerinin artırılması ve yüzde 5 paydan yararlanmamız gerekiyor. Bunun için de Denizli’ye özel bir yasa çıarılmalı. Başka türlü bu yasa olumsuz sonuçlar doğurabilir.

307 sıra sayılı Teklifin Aralık 2003'te TBMM'de görüşülmesi sırasında veto edilecek 5026 sayılı Kanunun yürürlügüne ilişkin 2. madde üzerinde CHP Grubu adına söz alan Ankara Milletvekili Oya Araslı, sabaha karşı devam eden Genel Kurul görüşmeleri ve değişiklik önergeleri arasında şu ifadeleri kullanmıştı:

İçtüzüğün gereği olan 48 saatlik süreler ne komisyon görüşmelerinde ne de Türkiye Büyük Millet Meclisine bu teklif inerken dikkate alınmadığı ... bu teklif de, tıpkı 308 sıra sayılı yasa teklifi gibi, belediyelerin coğrafî yapısını, belediye haritasını değiştirmektedir. ... Bu tür köklü değişikliklerin belli birtakım ölçütlere, ... ilkelere bağlı kalınarak yapılması gerekir. İlkönce bu ilkeler belirlenir, ondan sonra da iddia edildiği gibi, Türkiye'de bütün belediyelerin yapısı, bu ilkelere, bu ölçütlere göre tayin edilir; ama, biz, ne 307 sıra sayılı yasa teklifinde ne de 308 sıra sayılı yasa teklifinde bu ilkelerin, bu ölçütlerin ne olduğunu tespit edebilmek imkânına sahip olmadık. ... eşi benzeri görülmedik bir yöntemle yasa burada yazıldı. Teklif geldi; ama, yasa burada yazıldı. 308 sıra sayılı kanun teklifi için de aynı şey oldu, 307 sıra sayılı kanun teklifi için de aynı şey oldu. Teklif geldi; ama, içi burada boşaltıldı, burada, yeni birtakım önergelerle, yeni bir içerik verildi; çıkıyor gidiyor. Teklif sahibinin anlattıkları da havada kaldı; çünkü, onun da bu teklifi verirken yazmadığı bir yasa burada şekillendi.

5019 sayılı Kanun (önerisi) için görüşlerini belirtirken, 5026 sayılı Kanun (Teklifi) hakkında da fikrini kısaca açıklayan Toprak'ın (Karaman) (2003) görüşü ise şöyleydi:

Denizli belediyesi için hizmet bütünlüğü sağlanması yönüyle tek kademeli modele çevrilmesi (bütün belediyelerin bir araya toplanması) ile hizmet etkinliğinin sağlanması mümkün değildir. İki kademeli yönetsel yapıya (büyük kent modeli) dönüştürülmesi ve bunun için en az 7.500 nüfustan başlayacak yeni ilçelerin bu alan içinde oluşturulması gerekmektedir. 


\section{5. ÜÇÜNCÜ TASAVVUR: 5393 SAYILI BELEDIYYE KANUNUNUN 11/1. MADDESINCE KOMŞU BELDE VE KÖYLERIN DENIZLII BELEDIYESININ MAHALLESI OLUŞU ANLAMINDA BÜTÜNŞEHIR}

5393 sayılı Belediye Kanununun 11. maddesi 1. fikrasındaki tüzel kişiliğin sona erdirilmesi hükmünü ve bunun Denizli'de uygulanmasına yönelik gelişmeler dört dönemde incelenebilir: 1) 5215, 5272, 5393 sayı11 Belediye Kanunlarının yasalaşma dönemi (Mart 2004-Temmuz 2005), 2) 5393 sayılı Belediye Kanunu ile Denizli Belediyesi Meclisinde komşu belediye ve köylerin tüzel kişiliğinin sona erdirilmesi kararı arası dönem (Temmuz 2005-Nisan 2006), 3) Denizli Belediyesi Meclis kararı ile Üçlü Kararnameyle 2006/8352 sayılı sınır tespiti kararı arası dönem (Nisan 2006-Ağustos 2006), 4) 2006/8352 sayılı sınır tespiti kararı ile 2009 yerel seçimleri arası dönem (Ekim 2006-Mart 2009). Bu çerçevede, Belediye Kanununun 11/1 maddesindeki tüzel kişiliğin sona erdirilmesi düzenlemesi ve bunun Denizli'de uygulanmasıyla şekillenen Denizli için 3. tip bütünşehir belediyesi tasavvuru aşağıda hikâye edilmektedir.

5393 sayı11 Belediye Kanunundaki 11. madde hükmünü anlamak için 10. Cumhurbaşkanı Sezer'in geri gönderdiği 5215 sayılı Belediye Kanunu, 5026 sayılı Kanunu, 5216 sayılı Büyükşehir Belediyesi Kanunu hikâyelerini birlikte değerlendirilmelidir. 5216 sayılı Kanunla yeni büyükşehir belediyesi kurulması birisi il merkezi belediye ve sınırlarına 10 kilometre mesafedeki yerleşimler toplamında asgari 750.000 nüfus şartı olmak üzere getirilen kriterlerle, bu kriterlerin değiştiği ve il sınırlarında 750.000 nüfus şartına dönüldüğü Kasım 2012'ye kadar olan dönemde, zorlaştırıldığından başta büyükşsehir belediyesi olmak isteyen il merkezi belediyeler olmak üzere il ve ilçe merkezi belediyelerin, daha doğrusu kentlerin, yaşadıkları sorunlara kısmı çözüm olarak yeni Belediye Kanununda 4., 5., 8. ve 11. maddeler yer almıştı. 4. ve 8. madde benzeri hükümler daha önce de olmakla birlikte, belediye kuruluşunda 5.000 metre ve 5.000 nüfus daha önceki mesafe ve nüfus ölçütlerinde belirlenen rakamlardan daha yüksektir; 11. maddeyse ilk defa gündeme gelmiştir. 5393 sayılı Belediye Kanununun 11. Maddesine göre bir ana belediyenin sınırlarına $5 \mathrm{~km}$ mesafede kalan yerleşimler altyapı sorunları, genel imar düzeni ve temel altyapı hizmetlerinin aksaması veya gerekli kılması durumunda uzun bir prosedür sonucu üçlü/müşterek kararnameyle ana belediyeye katılabilir. 5393 say1l Belediye Kanununun genel ve madde gerekçelerinde sadece iki ilin adı geçmektedir: Hatay ve Denizli. 5393/11. maddenin gerekçesinde şunlar yer almaktadır:

Denizli ve Hatay illerimizde olduğu gibi bir çok belediye cadde ve sokaklarla birbirinden ayrılmış, görev ve yetkilerin kullanımı ile hizmetlerin sunumunda karmaşa yaşanmış, vatandaşlar karşılaştıkları sorunlarla ilgili olarak hangi belediyeye başvuracaklarını şaşırmış, imar denetimleri ve kaçak yapılaşma ile mücadele yeterince yapılamamış ve kentlerimiz hızla gecekondulaşmıştır. ... Ayrıca, bağlı olduğu il veya ilçe belediyesi ile nüfusu 50.000'in üzerinde olan bir başka belediyenin sınırına 5.000 metreden daha yakın hale gelen belediye ve köylerin; genel imar düzeni veya temel alt yapı hizmetlerinin gerekli kılması durumunda, yine Danıştayın görüşü alınarak İçişleri Bakanlı̆̆ının teklifi üzerine müşterek kararname ile tüzel kişiliklerinin sona erdirilerek ilgili belediyeye katılması öngörülmektedir.

5393 sayılı Belediye Kanununun "tüzel kişiliğin sona erdirilmesi” başlığı altında belediye ve köylerin ana belediyeye katılarak mahalleye dönüştürülmesini düzenleyen 11. maddesinin 1. fikrası aynen şöyledir:

Meskûn sahası, bağlı olduğu il veya ilçe belediyesi ile nüfusu 50.000 ve üzerinde olan bir belediyenin sınırına, 5.000 metreden daha yakın duruma gelen belediye ve köylerin tüzel kişiliği; genel imar düzeni veya temel alt yapı hizmetlerinin gerekli kılması durumunda, Danıştayın görüşü alınarak, İçişleri Bakanlığının teklifi üzerine müşterek kararname ile kaldırılarak bu belediyeye katılır. Tüzel kişiliği kaldırılan belediyenin mahalleleri, katıldıkları belediyenin mahalleleri hâline gelir. Tüzel kişiliği kaldırılan belediye ile köylerin taşınır ve taşınmaz mal, hak, alacak ve borçları katıldıkları belediyeye intikal eder.

"Sınır düzeltmesi” veya "sınır kararı" düzenlemesi kapsamında, 2006/8352 sayılı Üçlü Kararnamenin 12.08.2006 tarih ve 26257 sayılı Resmi Gazetede yayınlanmasıyla; Denizli İli Merkez İlçeye bağlı Akkale, Bereketli, Gümüşler, Kayhan, Kınıklı, Servergazi Hallaçlar, Üçler, Korucuk, Bağbaşı, Başkarcı, Gökpınar, Göveçlik Belediyeleri ile Bozburun, Eskihisar, Goncalı, Hisar, Kadılar, Karakurt, Saruhan, Şirinköy, Güzelköy (Yiğenağa), Karakova Köylerinin tüzel kişilikleri feshedilerek Denizli Belediyesi sınırları içine katılması 5393 sayılı Kanunun 11 inci maddesi uyarınca uygun görülünce Mart 2009 yerel seçimlerinde adı 
geçen yerleşimlerin tüzel kişilikleri sonlandırıldı. Bu katılımla, Denizli Belediyesinin sorumluluk sahası ve nüfusu da genişledi. Denizli Belediyesinin 2000 nüfusu 275.000'di. 2006 Ağustosunda üçlü kararnameyle onanan 11. Maddenin Merkez İlçede uygulanmasını Denizli Platformu büyükşehir belediyesine giden yol olarak yorumladı. Sınırlarına $5 \mathrm{~km}$ mesafedeki belediye ve köylerin Denizli Belediyesine katılmasından birkaç yıl sonra nüfus 500.000 civarına yükseldi. Denizli Belediyesinin nüfusunun ve alanının 5393/11. madde uygulamasıyla artması sonucu genişleyen yeni sınırlarından çizilecek $10 \mathrm{kmlik}$ alandaki nüfus da eklenince, 6360 sayılı il sınırlarında büyükşsehir belediyesi kuran Kanun öncesi dönemde bile, büyükşehir belediyesi statüsü için çizilecek 10 kilometrelik sınırların daha geniş olmasıyla daha fazla nüfus kapsanacaktı. Trabzon, Malatya ve Şanlıurfa'ya ilaveten hakkında çok kez büyükşehir belediyesi teklifi verilmiş il merkezi Denizli’nin, gerekli nüfus şartını taşıması halinde, büyükşehir belediyesi olması siyasi açıdan kolaydı; nitekim 6360'la bu gerçekleşti.

5393 sayılı Belediye Kanununun ölçek ve belediye kuruluşu açısından şu üç maddesi öne çıkmaktadır: 1) Belediye kuruluşunu sınırlayan ve asgari nüfusu 5.000 çıkartan 4. Madde. 2) Bir belde veya köyün veya bunların bazı kısımlarının meskûn sahasının, komşu bir beldenin meskûn sahası ile birleşmesi halinde iltihakı düzenleyen 8. Madde. 3) Ana belediyelerin sinırlarına $5 \mathrm{~km}$ mesafedeki belediye ve köylerin o kentsel alanda imar düzeni ve altyapı hizmetlerinin akamaması için il veya ilçe belediyelerine bağlanmasına olanak sağlayan 11/1. Madde. Belirli mesafedeki belediyelerin 11. madde uygulamasıyla ana belediyeye, akademik adıyla katma/birleştirme (bu düzenleme ve uygulamaları hakkında detaylı bilgi için bakınız: Arıkboğa, 2007; 2008a; 2008b; Çınar vd., 2013; Özgür, 2007; 2008a; 2008b; Torlak ve Sezer, 2005). Özellikle Tayfun Çınar, Bülent Duru, Can Umut Çiner ve Ozan Zengin'in proje ürünü Belediyenin Sinırları kitabı büyük ölçüde bu konuya ayrılmış olup Bolu, Denizli, Kütahya ve Kırıkkale örneklerini saha araştırmasına dayalı olarak derinlemesine ele almaktadır.

Kanundaki adıyla "iltihak" yoluyla katılması mümkün oldu. Denizli Belediyesi çevresindeki belde belediyelerinin ve köylerin tüzel kişiliğinin sona erdirilmesinin (katma/iltihakın) Denizli kentsel alanının yönetiminde uygunluğu tartışmalıydı. 5393'ün 11/1. maddesindeki çözüm, demokratiklik, etkililik, etkinlik, tercih, rekabet, optimal ölçek, hesap verebilirlik, kendi kaderini tayin, saydamlık, katılım açılarından sıkıntılıdır. Bu düzenlemeyle ana belediyelerin çevrelerindeki belediye ve köylerin "genel imar düzeni veya temel altyapı hizmetlerinin gerekli kılması durumunda" birleştirilmesi yolu açıldı. 11. maddedeki düzenleme, nüfusu ne olursa olsun tüm il ve ilçe belediyelerine iltihak ve birleşme yetkisi verir ve alınacak belediye ve köylerde yöneticiler ve/veya hemşehrilerin rızası aranmaz. Nüfusu birkaç binler seviyesindeki ilçe belediyesi bile, hakli gerekçe(ler) gösterdiği ve ilgili kurumlar uygun görüş verdiği takdirde, komşu belediye ve köyleri, kendisine dahil edebilir. 5393'ün 11/1'deki düzenleme, ana belediyenin sınırlarına $5 \mathrm{~km}$ mesafedeki belediye ve köylerin tek taraflı bir dizi kararla ana belediyeye mahalle statüsünde ilk yerel seçimlerde katılarak tüzel kişiliği sona erecek yerleşimler için gerekçeyi hazırlamasını zorunlu kılmaz; süreç valilik kararıyla da başlayabilir. Hukuki olarak, belediye meclisinin kararı valiliğin elini güçlendiren bir başlangıç olup ana sorumluluk valiliğe aittir. Denizli Belediyesi Meclisinin 11/1 kararını takiben Valilik, Danıştay, İçişleri Bakanlığı da aynı doğrultuda kararlar vermesinin de etkisiyle Üçlü Kararname imzalanmıştı. Denizli Belediyesi 5393-11/1'in kapsayacağı alana dair haritanın çizimiyle karara gerekçe oluşturacak ilk hazırlıkları yapsa da, 2006/8352 sayılı üçlü kararname yoluyla sınır tespiti kararına karşı açılan iptal davasında Belediye değil Valilik muhatap alınmıştı. 2006/8352 sayılı Denizli Sınır Tespiti Kararı (Üçlü Kararname) 5393 sayılı Belediye Kanunundan bir yıl 5393'ün öncülü olan 5215'den ise iki yıl sonra gerçekleşti. Karar Mart 2009'daki yerel seçimlerle birlikte tam olarak geçerli hale geldi.

Akşam Gazetesinin 22.11.2005 tarihli Ege Ekinde "Denizlili İşadamlarını Rahatlatan Müjdeler” başlıklı haberinde Belediye Başkanı Nihat Zeybekci’nin sözlerine yer verilmişti:

Bu kentte yaşayan bir insanın değeri 1 lira iken, Erzurum, Samsun ve İzmir'de yaşayan bir kişinin değeri 3 lira ediyor. Büyükşehir [Belediyesi] Yasası yaşamsal eşitsizlik yaratıyor. Bir köprü yapmaya kalkıyorsunuz, ayakları bir belediyede, gövdesi başka belediyede. Denizli'ye Bütünşehir Yasası şart. Mevcut Büyükşehir Yasası ile küçük kentlerin hakkı yeniyor. Devlet büyükşehirleri destekleyip sübvanse ederken, önemli kentleri unutuyor. 5393 Sayılı Belediye Yasası merkeze yakın belediyeler zengini 
Denizli'nin sorununu çözmeye yetmiyor. Denizli halen çevresinde 22 belde ile tam bir parçalanmışlık ve yetki kargaşası yaşıyor. Denizli'nin Büyükşehir [Belediyesi] olmasının yolu bütünşehirden geçiyor.

Denizli Belediyesi Meclisinde 7.4.2006 tarihinde oybirliğiyle Belediye sınırlarına $5 \mathrm{~km}$ mesafedeki yerleşimlerin tüzel kişiliklerinin ilk yerel seçimlerde kaldırılarak Denizli Belediyesine katılmasına dair karar alındı. Bu sayede Üçlü Kararnameyle 2006/8352 sayılı sınır tespiti kararına giden süreç başladı. Alınan karara destekler ve itirazlar oldu. Bu haberlerin bazıları 2006/8352 sayılı karar öncesindeydi. "Belediye Meclisi Denizli Sınırlarının Genişletilmesi Yönünde Karar Aldı” başlıklı 09.04.2006 tarihli haber (Zaman Gazetesi) şöyledir:

Denizli Belediye Meclisi, Nisan ayı olağan toplantılarının son gününde aldığı kararla, Cumhurbaşkanı Ahmet Necdet Sezer tarafindan 3 yıl önce bir kez daha görüşülmek üzere T.B.M.M.'ye iade edilen ve halen Mecliste bekleyen Denizli İli Bazı Belde ve Köylerinin Denizli Merkez Belediyesi ile Birleştirilmesine Dair Yasa Tasarısına [Teklifine] karşı, yeni süreç başlattı. Denizli Belediye Meclisi, 5393 Sayılı Belediye Yasasının 11. maddesine dayanarak ... Bereketli, Gümüşler, Kayhan, Kınıklı, Servergazi, Hallaçlar, Üçler Korucuk, Bağbaşı, Başkarcı, Gökpınar ve Göveçlik beldeleri ile Güzelköy, Karakova, Kadılar, Eskihisar, Hisarköy, Goncalı ve Karakurt köylerinin, Denizli Belediyesi... sahasına dahil edilmesi kararı aldı. Belediye Başkanı Nihat Zeybekci, yaptığı konuşmada, oybirliğiyle kararın alınmasına katkıda bulunanlara teşekkür ederek, amacın önce plan ve nüfus bütünlüğünü sağlamak, daha sonra büyükşsehir için gerekli olan 750 bin nüfus şartını yakalamak olduğunu söyledi. Küçük belediyeler nedeniyle yaşanan bölünmüşlüğün planlamada sıkıntı oluşturduğunu belirten Zeybekci, 'ileriye dönük planlamaların olduğu beldelerde projeleri uygulayamıyoruz. Bu karar onaylandığında, problemlerin birçoğu ortadan kalkacaktır" ... dedi. CHP'li üye Zafer Gönenç Denizli’nin büyükşehir yapılmasıyla ilgili parlamentonun bir yasa çıkarabileceğini belirterek, 'Meclisin aldığı bu karar da bir süreci başlatacaktır' diye konuştu.

Ayrıca Cankurtaran Belediyesi de 5747 sayılı Kanunun Geçici 1'inci maddesinin 4'üncü fikrası uyarınca köye dönüştürülmesi kararlaştırılmışken köye dönüşmemek için Cankurtaran Belde Belediyesi Meclisinde beşe dört çoğunluk oylarıyla Denizli Belediyesi'ne 5393 sayılı Kanunun 8. Maddesindeki düzenlemeden yararlanmak suretiyle mahalle katılmıştır (Çınar vd, 2013: 187-191). Türkiye'de bu yolla il veya ilçe merkezi belediyeye katılan belediye sayısı oldukça sınırlı olmakla birlikte Denizli dışında da örnekleri bulunmaktadır.

\section{DÖRDÜNCÜ TASAVVUR: 6360 SAYILI KANUNLA DENIZLII İL SINIRLARINDA BÜYÜKŞEHİR BELEDIYYESİ KURULMASI ÇERÇEVESINDE BÜTÜNŞEHİR SÖYLEMI}

Türkiye için Denizli dahil toplamda beşinci, Denizli özelinde dördüncü, Denizli dışında Türkiye için üçüncü tip bütünşehir belediyesi söylemi ise, yukarıdaki tablolarda da özetle anlatıldığ 1 üzere, 6360'la ortaya çıkan il mülki sınırlarında büyükşehir belediyesini ifade etmektedir. Bu söylem aralarında Denizli'nin de bulunduğu 30 büyükş̧ehir belediyesi ile Batman, Sivas, Elazığ, Afyonkarahisar ve Zonguldak'ın da aralarında bulunduğu beş kadar büyükşehir belediyesi statüsü elde etmesi değişik çevrelerde gündeme gelen ve il nüfusu 500.000-750.000 aralığında kalan diğer bazı illerde veya iller için de konuşmaktadır.

6360 sayılı yasa büyükșehir belediyesi sayısını 16'dan 29'a çıkartmıștır. İlk üçü 1984 yılında kurulan büyükşsehir belediyelerine 1985-1989 döneminde beş adet daha eklenmiş ve sayıları 1993 y1lında 7 yeni büyükşsehir belediyesi ile 8'den sayı 15'e ulaşmıştı 1993 yılından 2012 y1lına kadar geçen 20 yıllık sürede sadece Sakarya Büyükşehir Belediyesi 2000 y1lında kurulabilmişken 2012 y1lında 13 büyükşsehir belediyesi daha kurulması kanunlaşmıştı. Buna 6447 sayılı Kanunla sonradan nüfusu 731.000'e düşen Ordu da 2013 yılında eklenmişti. Bu 14 yeni büyükşehir belediyesinin Ordu, Muğla, Tekirdağ, Mardin gibi bazıları için herhangi bir çaba ve tasarı daha önce gündeme gelmemiş̧i, Balıkesir, Aydın, Hatay, Manisa içinse bu çaba çok cılızd1.

2001-2011 dönemindeki 59., 60., 61. ve 62. Hükümetler 750.000 asgari nüfus şartı karş1lamadıkça yeni büyükşehir belediyesi kurulmasına karş1 gözükmekteydi. 2010-2014 döneminde 62. Hükümet ve özellikle Başbakan Recep Tayyip Erdoğan 2012 yılı başlarında büyükşehir belediyesi kurulmasıyla ilgili AK Parti Hükümetlerinin mevzuata da yansımış olan önceki tercihini tersine çevirdi. 5216 sayılı BşB Kanunundaki 
kuruluş şartları Başbakanın beyanatları, kanun tasarısı, Parlamento kararıyla tersine çevrildi. 6360 sayılı Kanunla büyükşehir belediyesi kuruluşu hem kolaylaştırıldı hem de 2012'de tek seferde rekor sayıda (13) büyükşehir belediyesi birden kuruldu. 6360'la mevcut 16 büyükşehir belediyesinden 14'ünün sınırları genişletildi, tüm büyükşehir belediyelerinde belde ve köyler mahalleye dönüştürüldü, ikisi Zonguldak' ta toplam 26 yeni ilçe kuruldu, büyükşehir belediyesi statüsü bulunan illerde il özel idareleri kapatıldı ve genelde yerel yönetim sisteminde özelde büyükşsehir belediyelerinde başka önemli değişiklikler yapıldı.

2000'li yıllarda büyükşehir belediyeleri sınırları dışında kalan (ilçe merkezi olmayan, kaymakamsız) bucak merkezi veya diğer belde belediyeleri açısından Zonguldak (Kilimli ve Kozlu - Merkez; Kandilli ve Gülüç - Karadeniz Ereğli, Filyos - Çaycuma), Mersin (Atakent ve Taşucu - Silifke, Yenice - Tarsus, Kargıpınarı - Erdemli), Aydın (Ortaklar - Germencik, Atça - Sultanhisar, Davutlar - Kuşadası gibi), Hatay (Serinyol ve Harbiye - Antakya, Karaağaç ve Denizciler - İskenderun, Payas - Dörtyol), Muğla (Armutalan - Marmaris, Kemer, Göcek, Karaçulha ve Ölüdeniz - Fethiye), Antalya (Mahmutlar, Oba ve Konaklı Alanya, Ilıca ve Side - Manavgat) ile birlikte en çok sayıda ve en ilginç örneklere sahip illerden birisi Denizli (Bağbaşı, Üçler, Gümüşler ve Kınıklı - Merkez gibi) iken bugün de en küçük büyükşehir ilçe belediyelerine Konya ve Eskişehir ile birlikte sahip illerden birisi konumuna sürüklenmiştir.

Türkiye Belediyeler Birliği’nin 2014 yılında yayımladığı 10/4/2014 tarih ve 28968 sayılı Resmi Gazetedeki düzenlemeyi aktaran son norm kadro yönetmeliği ve ek tablolarında yer alan nüfus bilgileri esas alındığında Türkiye'de Mart 2014 itibariyle büyükşehir belediyesi sınırlarında nüfusu 10.000'in altında 49 belediye bulunmaktadır. Bunlardan en küçüğ̈̈ 1.830 nüfusuyla Konya ilinin Yalıhüyük belediyesi iken en büyüğü de yine 9.928'lik nüfusuyla Konya'nın Güneysınır Belediyesidir. Büyükşehir belediyeleri içinde 10.000 'den az ilçe belediyeleri içindeki 49 belediye arasında Eskişehir ve Konya'nın 10'ar, Trabzon ve Kayseri'nin 3'er belediyesi bulunmaktadır. 10.000 nüfus altındaki büyükşehir ilçe belediyelerinden, dolayısıyla ilçelerinden, beşi (Baklan 5.934; Babadağ 6.707; Beyağaç 7.116; Bekilli, 7.751; Çardak 9.386) Denizli ili / büyükşehir belediyesi sınırlarında yer almaktadır. Denizli'nin ve Türkiye'nin en küçük nüfuslu ilçelerinden birisi olan Akköy’ün de Merkez İlçenin önemli bir kısmını alarak Pamukkale ismiyle 311.496 nüfusa ulaşmak suretiyle bu listeye girmekten kurtulduğu hatırlanmalıdır. Ayrıca Denizli'nin Güney 10.796 ve Bozkurt 12.279 ilçeleri de yine küçük nüfuslu ilçeler arasındadır.

İlçe nüfuslarını ve coğrafi büyüklüklerini daha dengeli hale getirmek için Bekilli'nin tekrar Çal'a bağlanması, Bozkurt ve Çardak ilçelerinin birleştirilmesi, coğrafi alan olarak da küçük olan Beyağaç ilçesinin tekrar Kale İlçesine bağlanması, Merkez İlçedeki bazı yerleşimlerin Babadağ ilçesine bağlanması veya Babadağ ilçesinin Sarayköy İlçesine bağlanması, Çal İlçesinin beldesi iken önce 5747 sayılı Kanunla köye sonra da 6360 sayılı Kanunla mahalleye dönüştürülen Denizler yerleşimi ve civarındaki mahallelerin Baklan ilçesinin kapatılmaması halinde Baklan'a bağlanması, Baklan ilçesi kapatılırsa bu ilçenin yerleşimlerinin yakınlık ve ilgilerine göre kısmen Bozkurt'a kısmense Çal ve Çivril ilçelerine bağlanması, askeri sahanın üstünün Merkezefendi'den ayrılarak ikiye bölünmesi, Pamukkale İlçesinin kuzeyinde Uzunpınar mahallesi (eski belediyesi) merkezli yeni bir ilçe kurularak Pamukkale'nin özellikle coğrafi büyüklük açısından küçültülmesi derinlemesine bir araştırma olmaksızın ilk etapta akla gelebilecek ve ilçelerin nüfus ile arazi büyüklükleri açısından dengeyi sağlamaya yardımcı olabilecek, disiplinlerarası kapsamlı çalışma gerektiren, öncü önerilerdir. Denizli Çardak Havalimanının sahası Bozkurt ve Çardak ilçelerine taşmakta olup Bozkurt ilçesi Çardak'tan ayrılmakla birlikte nüfus olarak Çardak'tan daha büyüktür. Türkiye'de büyükşehirlerin merkezindeki metropoliten alanın ilçeleri dışında kalan coğrafyalar dikkate alındığında, Bozkurt ve Çardak fiziki, coğrafi ve askeri saha gibi engeller olmadan düz bir arazi üzerinde ilçe merkezleri birbirine en yakın ve en kolay ulaşılabilen ilçeler arasındadır. Afyon ilinin Başmakçı ve Dazkırı ilçelerinin Denizli iline bağlanması, Fethiye'de bir il kurulması halinde Çameli İlçesinin de Fethiye'ye bırakılması da diğer önerilerdir.

Üç komşusu (Aydın, Muğla, Manisa) üç komşusu da (Uşak, Afyonkarahisar, Burdur) büyükşehir değildir. Denizli daha önce İzmir, Bursa, Ankara, Konya, Antalya büyükşehir belediyeleri beşgeni arasındaki en kalabalık şehirdir. 963.464'lük nüfusuyla 21. en kalabalık ili ve büyükşehir belediyesidir. Aydın, Van ve Kahramanmaraş Denizli’yi az bir nüfus farklıyla aşmaktadır. 
İsim değiştirerek genişleyen büyükşehir ilçe belediyesi (Akköy - Pamukkale). 2003 yılı sonundaki 5026 sayılı Kanunla Denizli Belediyesinin mahallesine dönüşmek üzereyken Kanun veto edilince varlı̆̆ını Pamukkale belde belediyesi varlığını 2003 yılı sonundaki özel kanunla mahalleye dönüşecekken Kanunun veto edilmesiyle varlığını Mart 2014 yerel seçimleri sonuçlarına kadar korudu. Aslında Pamukkale yerleşiminin bir kısmı geçmiş̧e Denizli Belediyesi Mahallesi olmuştu. Pamukkale-Karahayıt ve civarı özel çevre koruma bölgesi (ÖÇKB) statüsünden dolayı 1/25.000'lik çevre düzeni planına sahipti. Pamukkale ve Merkezefendi'nin sınırları eski Denizli Belediyesi sınırları içerisindeki kesişme alanlarında suni bir görüntü vermektedir, oysa ana karayolları veya diğer doğal ayraçlar bu iki ilçenin sınırlarının belirlenmesinde kullanılabilirdi. Pamukkale İlçesinin zigzaglı ve eski Denizli Belediyesi içerisine mahalleler bazında giren sınırının en büyük faydası Pamukkale Üniversitesinin aynı adı taşıyan Pamukkale İlçesi ve dolayısıyla Pamukkale Büyükşsehir İlçe Belediyesi sınırlarında kalması olmuştur.

İsmi Akköy'den dönüştürülerek ve yetki sahası genişletilerek oluşturulan Pamukkale İlçe Belediyesi 311.000'lik nüfusuyla en büyüğü 914.000'lik nüfusuyla Ankara ilinin Çankaya ilçesi olan büyük ilçeler arasında 56. Kalabalık belediyesidir. Buna nüfusu Pamukkale'den büyük olan ve büyükşehir belediyesi statüsüne sahip olmayan Sivas (315.107), Elazı̆̆ (332.810), Batman (369.478) il merkezi belediyeleri de katıldığında Pamukkale Türkiye'nin 59. büyük belediyesi olmaktadır. 963.464'lik Denizli Büyükşehir Belediyesinin yaklaşık üçte birlik kısmı Pamukkale Büyükşehir İlçe Belediyesinde yaşamaktadır. Denizli, Batman ve Eskişehir il nüfusu yarım milyonun üzerindeki iller arasında nüfusun yarıdan fazlası il merkezinde yaşayan, çevre ilçelerin nüfuslarının çoğunun küçük hatta çok küçük olduğu iller arasındadır. Bunlardan Eskişehir 1993 yılından buyana büyükşehir belediyesi iken Batman bu statüye Haziran 2014 itibariyle halen sahip değildir. Denizli'deki bu merkez - çevre ilçeler hesaplaması büyükşehir belediyesi öncesinde Merkez İlçe üzerinden şimdi ise Pamukkale ve Merkezefendi ilçeleri üzerinden yapılması sağlıklı olacaktır.

Denizli ilinde büyükşehir belediyesi statüsü diğer birçok ilden farklıdır; çünkü hem büyükşehir belediyesi için kimisi bütünşehir diye anılan -bazısı uygulanan bazısı tasavvur düzeyinde kalan- söylemler ve düzenlemelerle de nispeten uzun süredir desteklenmiştir. Denizli'de büyükşehir belediyesi statüsü konusundaki çabalar 1993 yılından başlamak üzere yaklaşık 20 yıl sürmüştür, toplamda sayıları 30'a ulaşan büyükşehir belediyeleri içinde bu derece uzun süredir çaba gösteren sayısı az olup bu durum Şanlıurfa, Kahramanmaraş, Malatya ve Trabzon ile sınırlıdır.

Denizli’de kullanılan bütünşehir terimleri anlam ve içerik değiştirip önce İzmir gibi komşu illere sonra da tüm Türkiye'ye yayılarak bugün tüm büyükşehir belediyelerinde ve bu statü için mücadele eden Sivas, Zonguldak ve Elazığ gibi diğer orta ölçekli kentlerde de kullanılır olmuştur. 


\section{KAYNAKLAR}

ARIKBOĞA, Erbay (2007) "Yerel Yönetimlerde Ölçek Sorunu Ve Belediye Reformu”, V. KAYFOR (Kamu Yönetimi Forumu), 2007, 18-20 Ekim, Kocaeli. http://mimoza.marmara.edu.tr/ earikboga/yayin/olcek.pdf

ARIKBOĞA, Erbay (2008a) "Türkiye'de Belediyelerin Büyüklüğü ve Kentin Bütünlüğü Sorunu: Reform ve Uygulama Analizi”, F.N. Genç, A. Yılmaz, H. Özgür, Dönüssen Kentler ve Değişen Yerel Yönetimler, Gazi Kitabevi, Ankara, ss. 299-330.

ARIKBOĞA, Erbay (2008b) "5393/11: Devam Eden/Edemeyen Reform”, 1. Ulusal Yerel Yönetimler Sempozyumu Bildiriler Kitabı, Erkam Matbaası, İstanbul, ss. 17-34.

AYGÖREN, Ali (2001) “Ali Aygören Konuşması”, Büyükşshir Deneyimleri Işlğında Denizli Panel ve Forumu, Denizli, 30.03.2001, Mimarlar Odası Genel Merkezi ve Denizli Şubesi, Ankara, ss. 5-6, 15-17.

CİĞEROĞLU, Mısra (2007) Denizli Kentsel Alanının Yönetimi Alternatifleri, Yayımlanmamış Yüksek Lisans Tezi, Pamukkale Üniversitesi, Denizli.

ÇINAR, Tayfun, Bülent DURU, Can Umut ÇİNER, Ozan ZENGİN (2013) Belediyelerin Sinırları, TODAİE, Ankara.

ÇINAR, Tayfun, Can Umut ÇİNER, Ozan ZENGİN (2009) Büyükşehir Yönetimi Bütünleştirme Süreci, TODAİE, Ankara.

EKE, Ali Erkan (1982) Anakent Yönetimi ve Yönetimlerarası İlişkiler, Ankara Üniversitesi, Siyasal Bilgiler Fakültesi Yayınları, Ankara.

GÜLER, Birgül (1987) "Büyük Kentler İçin Yönetim Arayışları”, Türk İdare Dergisi, Sayı 374, Mart, ss. 112-143.

GÜNGÖR, Hayrettin (2012) "Yeni Büyükşehir Yönetimi ve Geçiş Nedenleri", Illler ve Belediyeler Dergisi, 774-775, ss. 19-31.

HÜRRIYET GAZETESİ (2003) Sezer'den 'Seçim Yatırımı' Yasasina Veto, 30 Aralık 2003, http://hurarsiv.hurriyet.com.tr/goster/haber.aspx?id=192897

KELEŞ, Ruşen (2012a) Yerinden Yönetim ve Siyaset, Cem Yayınevi, İstanbul.

KELEŞ, Ruşen (2012b) “Anakentlerin Dünü, Bugünü ve Yarını”, Kentsel ve Bölgesel Araştırma Sempozyumu -3, 6-7 Aralık, 2012, Gazi Üniversitesi, Ankara.

ÖZGÜR, Hüseyin (2007) "Orta Ölçekli Kentsel Alanların Yönetimine İlişkin Alternatifler”, Hüseyin Özgür ve Muhammet Kösecik (Editörler), Yerel Yönetimler Üzerine Güncel Yazılar -II: Uygulama, Ankara, Nobel Yayın Dağıtım, ss. 100-142.

ÖZGÜR, Hüseyin (2008a) "Yerel Siyaset Perspektifinden Bakışla Büyükşehir Belediyelerinde Kentsel Alan Yönetimi Uygulamaları", Yerel Siyaset, 1. Bask, Okutan Yayınc1lı,, İstanbul, 125-166

ÖZGÜR, Hüseyin (2008b) "Denizli Kentsel Alanının Yönetiminde Söylemden Eyleme Bütünşehir Belediyesi Tasavvurları: Ali Aygören Teklifi (2001), Denizli’ye Özel Kanun Teklifi (2003), Belediye Kanununun 11. Maddesi (2006)”, F. Neval Genç, Abdullah Yılmaz, Hüseyin Özgür, (Editörler), Dönüşen Kentler ve Değişen Yerel Yönetimler, Ankara, Gazi Kitabevi, 239-298. 
ÖZGÜR, Hüseyin (2009) "Denizli’nin Büyükşehir Belediyesi Statüsü Elde Etme Mücadelesi: 1993-2005”, Kentsel Ekonomik Araştırmalar Sempozyumu -II (KEAS'05), Bildiriler Kitabı, Ankara, DPT ve PAÜ, 328348.

ÖZGÜR, Hüseyin (2012) "Metropolitenleşme Sürecindeki Denizli Kentsel Alanlarının Yönetiminde Dört Dönem: Kapsamlı Mücavir Alan, İdari Parçalanma, Bütünşehir, Büyükşehir Belediyesine Geçiş”, Kentsel ve Bölgesel Araştırmalar 3. Sempozyumu (KBAM 2012) Kent Bölgeler, Metropoliten Alanlar ve Büyükşehirler Değişen Dinamikler ve Sorunlar, 6-7 Aralık 2012, ODTÜ, Bildiriler Kitabı, ss. 313-326.

ÖZGÜR, Hüseyin ve Muhammet KÖSECIK (2006) "Management Problems of Denizli Urban Field and Other Middle-Sized City Regions in Turkey: Assessing Alternative Administrative Models", First Bi-Annual EURA (European Urban Research Association) Conference: Cities in City Regions, 11-14.5.2006, Warsaw, Poland.

ÖZGÜR, Hüseyin, Muhammet KÖSECIKK ve Mısra CíĞEROĞLU (2007) "Denizli Kentsel Alanı İçin Geçmiş ve Güncel Yönetim Alternatifleri”, Kamu Yönetimi Sempozyumu (KAYSEM) -III; Planlama ve Bölgesel Gelişme: Deneyimler ve Yeni Arayışlar, Denizli Valiliği, Denizli Belediyesi, Pamukkale Üniversitesi, 15-17.11.2007, Denizli.

ÖZGÜR, Hüseyin; Pınar SAVAŞ YAVUZÇEHRE ve Mısra CİĞEROĞLU (2007a) "Türkiye'de Kentsel Alanların Yönetimi Sorunu", Atilla Göktürk vd. (Editörler), Kamu Yönetimi Forumu (KAYFOR IV): Kuramdan Uygulamaya (Yönetim ve Reform) Bildiriler Kitabı, 8-10 Kasım 2006, Muğla Üniversitesi, Muğla Belediyesi, 245-262.

ÖZGÜR, Hüseyin; Pınar SAVAŞ YAVUZÇEHRE ve Misra CİĞEROĞLU (2007b) "Türkiye'de Orta Ölçekli ve Metropoliten Kentsel Alanların Yönetimi”, Bilal Eryılmaz, Musa Eken, Mustafa Lütfi Şen (Editörler), Кати Yönetimi Yazıları: Teoride Değişim, Yeniden Yapılanma, Sorunlar ve Tartışmalar, Ankara, Nobel Yayın Dağıtım, ss. 475-513.

SAVAŞ YAVUZÇEHRE, Pınar (2011) Kentsel Mekanda Değişim: Denizli, (Gözden Geçirilmiş) Basılı Doktora Tezi, Süleyman Demirel Üniversitesi, Denizli Belediyesi Kültür Yayınları, Denizli.

TORLAK, S. Evinç ve Yasin SEZER (2005) "Büyükşehir Belediye Reformu Üzerine Bir Değerlendirme", Hüseyin Özgür ve Muhammet Kösecik (Editörler), Yerel Yönetimlerde Güncel Konular -I: Reform, Nobel Yayın Dağıtım, Ankara.

TUZCUOĞLU, Ferruh (2003) Metropoliten Yönetim, Sakarya Kitabevi, Adapazarı.

YILMAZ, Abdullah ve Yavuz BOZKURT (2008) "Kütahya'da Mücavir Alan Sorunları: Üçler Belediyesi Örneği”, F. Neval Genç, Abdullah Yılmaz, Hüseyin Özgür, (Editörler), Dönüşsen Kentler ve Değişen Yerel Yönetimler, Ankara, Gazi Kitabevi, 379-391. 